\section{OPEN ACCESS}

Edited by:

$\mathrm{Li} \mathrm{Li}$,

Capital Medical University, China

Reviewed by:

Laurent Metzinger,

University of Picardie Jules Verne,

France

Atefe Abak,

Tabriz University of Medical Sciences,

Iran

Ilgiz Fanilevich Gareev,

First Affiliated Hospital of Harbin Medical University, China Hazha Hidayat,

Salahaddin University, Iraq

Reyhane Eghtedarian,

Shahid Beheshti University, Iran

${ }^{*}$ Correspondence:

Mohammad Taheri

Mohammad_823@yahoo.com

Noormohammad Arefian narefian@yahoo.com

Received: 21 September 2021

Accepted: 28 October 2021

Published: 19 November 2021

Citation:

Ghafouri-Fard S,

Shirvani-Farsani Z, Hussen BM,

Taheri M and Arefian N (2021)

Emerging Impact of Non-coding

RNAs in the Pathology of Stroke.

Front. Aging Neurosci. 13:780489.

doi: 10.3389/fnagi.2021.780489

\title{
Emerging Impact of Non-coding RNAs in the Pathology of Stroke
}

\section{Soudeh Ghafouri-Fard', Zeinab Shirvani-Farsani2, Bashdar Mahmud Hussen ${ }^{3}$, Mohammad Taheri4* and Noormohammad Arefian ${ }^{5 *}$}

\begin{abstract}
' Department of Medical Genetics, School of Medicine, Shahid Beheshti University of Medical Sciences, Tehran, Iran, ${ }^{2}$ Department of Cell and Molecular Biology, Faculty of Life Sciences and Technology, Shahid Beheshti University, Tehran, Iran, ${ }^{3}$ Department of Pharmacognosy, College of Pharmacy, Hawler Medical University, Erbil, Iraq, ${ }^{4}$ Institute of Human Genetics, Jena University Hospital, Jena, Germany, ${ }^{5}$ Skull Base Research Center, Loghman Hakim Hospital, Shahid Beheshti University Hospital, Tehra, Iran
\end{abstract}

Ischemic stroke (IS) is an acute cerebral vascular event with high mortality and morbidity. Though the precise pathophysiologic routes leading to this condition are not entirely clarified, growing evidence from animal and human experiments has exhibited the impact of non-coding RNAs in the pathogenesis of IS. Various IncRNAs namely MALAT1, linc-SLC22A2, linc-OBP2B-1, linc_luo_1172, linc-DHFRL14, SNHG15, linc-FAM98A-3, H19, MEG3, ANRIL, MIAT, and GAS5 are possibly involved in the pathogenesis of IS. Meanwhile, lots of miRNAs contribute in this process. Differential expression of IncRNAs and miRNAs in the sera of IS patients versus unaffected individuals has endowed these transcripts the aptitude to distinguish at risk patients. Despite conduction of comprehensive assays for evaluation of the influence of IncRNAs/miRNAs in the pathogenesis of IS, therapeutic impacts of these transcripts in IS have not been clarified. In the present paper, we review the impact of IncRNAs/miRNAs in the pathobiology of IS through assessment of evidence provided by human and animal studies.

Keywords: IncRNA, miRNA, stroke, expression, biomarker

\section{INTRODUCTION}

Ischemic stroke (IS) is an acute cerebrovascular event with high mortality and morbidity. This disorder is the third most frequent cause of mortality in Western regions of the world (Feigin et al., 2015). Current treatments for IS include thrombolysis, mechanical thromboectomy and neuroprotective therapies (Liaw and Liebeskind, 2020). Although the exact pathophysiologic routes leading to this condition are not entirely clarified, growing evidence from animal and human experiments has exhibited the impact of non-coding transcripts in the pathogenesis of IS (Zhu et al., 2019). These transcripts are highly variable in the terms of size, function, genomic location and conservation, yet in a broad classification they can be categorized based on their size to small versus long non-coding RNAs (lncRNAs). Small non-coding RNAs have some subclasses among them are microRNAs (miRNAs). Both lncRNAs and miRNAs have regulatory impacts on gene expression but via different routes. Being firstly discovered in 1993 in C. elegans (Lee et al., 1993),

Abbreviations: AF, atrial fibrillation; AUC, area under curve; ceRNAs, competing endogenous RNAs; GO, gene ontology; HS, hemorrhagic stroke; hs-CRP, high-sensitivity C-reactive protein; IS, Ischemic stroke; LAA, large-artery atherosclerosis; lncRNAs, long non-coding RNAs; MCAO, middle cerebral artery occlusion; miRNAs, microRNAs; NIHSS, NIH Stroke Scale; PBMCs, peripheral blood mononuclear cells; ROC, receiver operating characteristic; TIA, transient ischemic attack. 
miRNAs comprise an ever-growing type of non-coding RNAs that target specific sequences in the $3^{\prime}$ untranslated regions of genes, then decreasing their expression via mRNA degradation or translation blocking (O'Brien et al., 2018). These transcripts are about 22 nucleotides in length. They can hypothetically target almost any gene in the human genome. However, the extent of miRNA response elements complementarity defines their route of action, i.e., AGO2-dependent cleavage of target transcript or RISC-associated translational suppression (Jo et al., 2015). Besides, a number of miRNAs might influence gene expression at transcriptional and post-transcriptional stages within the nucleus (O'Brien et al., 2018). However, this mode of action has not been fully discovered. The dynamic nature of miRNA-associated gene regulation potentiates them as tools for regulation of gene expression in a cell type/situation-specific mode since several events such as alternative splicing events, polyadenylation state and the presence of cell type-specific RNA binding proteins affect miRNA response elements (O'Brien et al., 2018). LncRNAs are another group of transcripts with fundamental roles in the regulation of gene transcription via several modes including acting as signal, decoy molecules, scaffolds, guide and enhancer transcripts. The chief mode action of lncRNAs is their role in the regulation of transcription in reaction to numerous stimuli through acting as molecular signals (Fang and Fullwood, 2016). Although they generally do not have open reading frame, many of them have similar characteristics with protein-coding genes among them are the presence of $5^{\prime}$ cap, poly A tail and alternative splicing events (Cheng et al., 2005; Derrien et al., 2012). Through participating in chromatin configuration alteration, interaction with chromatin structures, acting as competing endogenous RNAs (ceRNAs) or natural antisense lncRNAs, lncRNAs contribute in the pathogenesis of human disorders (Fang and Fullwood, 2016). Figure 1 depicts the role of a number of non-coding RNAs in the pathobiology of IS through different signaling pathways particularly PI3K/AKT and NF-к $\beta$.

\section{HUMAN STUDIES}

\section{Long Non-coding RNAs and Ischemic Stroke}

Assessment of expression of lncRNAs has been the focus of numerous studies conducted in human subjects. For instance, a high throughput study has been performed on blood specimens of patients with IS and controls who have been matched with cases in terms of vascular risk factors. The study has revealed differential expression of approximately 300 lncRNAs between IS group and male controls, while 97 lncRNAs have been differentially expressed between IS group and female controls. Notably, some of differentially expressed lncRNAs have been shown to reside in genomic regions formerly recognized as IS risk loci namely lipoprotein, lipoprotein(a)-like 2, ABO blood group, prostaglandin 12 synthase, and $\alpha$-adducins (Dykstra-Aiello et al., 2016). Another study has reported distinct lncRNAs signatures in peripheral blood mononuclear cells (PBMCs) among patients with IS, transient ischemic attack (TIA) and healthy subjects.
Notably, expressions of linc-DHFRL1-4, SNHG15, and lincFAM98A-3 have been substantially increased in IS patients versus healthy controls and TIA patients. Expression of linc-FAM98A-3 has been returned to normal level by day 7, whereas SNHG15 levels have been continued to be high during the follow-up period, demonstrating the capability of lncRNAs to observe IS dynamics (Deng et al., 2018). Another microarray-based assay has reported up-regulation of 560 and down-regulation of 690 lncRNAs in IS patients versus controls among them have been lncRNAs ENST00000568297, ENST00000568243, and NR_046084. Dysregulated lncRNAs have been predicted to partake in IS pathology by modulating central miRNAs, mRNAs, or IS-associated pathways (Guo et al., 2018). Assessment of lncRNA signature at two time points after IS has revealed differential expression of 3,009 and 2,034 lncRNAs $24 \mathrm{~h}$ and 7 days after IS, respectively. These results have shown the impact of IS on lncRNA signature at both the acute and subacute phases. Notably, expression of lncRNAs in the processing and presentation processes of antigens have been increased at $24 \mathrm{~h}$ and returned to basal amounts on day 7 following IS. Besides, expressions of inflammatory mediator regulation of TRP channels and GABAergic synapses have been decreased on day 7 following IS (Zhu et al., 2018). Levels of H19 in the circulation of patients with IS have been positively correlated with the National Institute of Health Stroke Scale Scores of the patients in in three time points following stroke attack. Mechanistically, H19 silencing could reduce expression of neurogenesis related proteins. In addition, H19 precludes the development of neurogenesis after IS via p53/Notch1 pathway (Wang et al., 2019a). Another experiment has reported association between H19 and Acute Stroke Treatment (TOAST) subclasses of atherosclerotic patients. Forced over-expression of H19 has enhanced ACP5 expression, increased cell proliferation and blocked cell apoptosis. Up-regulation of H19 has increased the plaque size in the animal model, thus H19 participates in the atherosclerotic processes and surges the risk of IS through increasing ACP5 levels (Huang et al., 2019). RMST is another upregulated lncRNA in the plasma specimens of IS patients (Hou and Cheng, 2018). A previous study in Chinese Han population has shown over-expression of ANRIL in IS patients parallel with down-regulation of CDKN2A. The rs2383207 and rs1333049 SNPs have been associated with risk of IS in male subjects (Yang et al., 2018). Another study has reported higher levels of ANRIL in patients with the atrial fibrillation (AF) and ischemic stroke compared with AF patients without IS. Serum levels of ANRIL have been correlated with the NIHSS and the mRS scores (Zeng and Jin, 2020). Table $\mathbf{1}$ gives a summary of human studies reporting elevation of lncRNAs in IS.

Contrary to two mentioned studies in the previous section, Feng et al. have demonstrated decreased levels of ANRIL in plasma specimens of patients with acute IS patients versus controls (Feng et al., 2019). ZFAS1 is another down-regulated lncRNA in IS patients. Moreover, expression of ZFAS1 in patients with large-artery atherosclerosis (LAA) stroke has been lower compared with those with non-LAA stroke and controls. In addition, ZFAS1 expression has been lower in the small vessel occlusion group compared with cardioembolism 


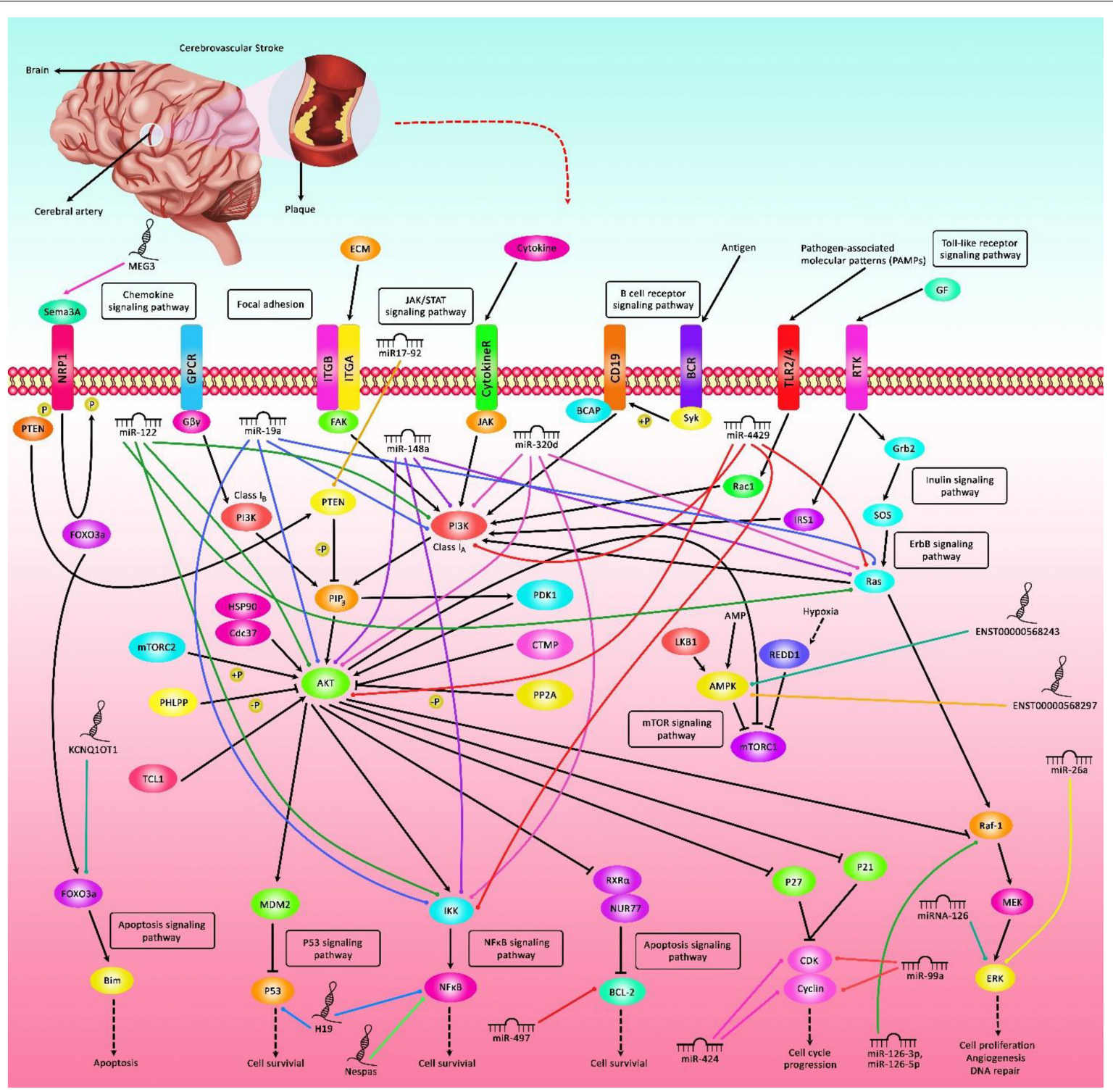

FIGURE 1 | A schematic representation of the interaction between non-coding RNAs and various signaling cascades in ischemic stroke (IS). Differential expression of IncRNAs as well as miRNAs could have an important role in the pathogenesis of IS. Various miRNAs such as miR-19a, miR-122, miR-148a, miR-320d, and miR-4429 via targeting AKt, PI3K, Ras, and IKK could modulate expression of genes leukocytes, thus affecting the course of IS. In addition, miR-497 by regulating the expression levels of $\mathrm{Bcl}-2$ and $\mathrm{Bcl}-\mathrm{w}$ could induce ischemic neuronal death. Additionally, IncRNA H19 via directly targeting P53 could suppress neurogenesis following IS through p53/Notch1 axis. Furthermore, MEG3 could promote cell survival and reduce cell apoptosis via modulating the expression of Sema3A. Besides, KCNQ1OT1 through modulating the expression of FOXO3 could enhance brain injury and induce autophagy in IS.

(Wang et al., 2019b). FLJ23867, H3F3AP6, TNPO1P1 are also among lncRNAs which are down-regulated in IS PBMCs compared with control PBMCs (Zhu et al., 2019). An lncRNA profiling using RNA-seq method and subsequent KEGG pathway and gene ontology (GO) enrichment assays have shown downregulation of RPS6KA2-AS1 and lnc-CALM1-7 in exosomes retrieved from sera of patients with acute minor IS (Xu et al., 2020). Table 2 gives a summary of human studies that displayed under-expression of lncRNAs in IS.

ANRIL low-expression has been determined as a marker of better recurrence-free survival in of AF patients with IS. Based on the outcomes of Cox regression model, serum levels of ANRIL, NIH Stroke Scale (NIHSS) score, infarct volume, and smoking have been the risk factors for AF with IS (Zeng and Jin, 2020). Another study has reported that down-regulation of ANRIL in acute IS can differentiate these patients from healthy subjects with area under curve (AUC) of 0.759. Besides, expression levels of this lncRNA has been negatively correlated with NIHSS score and high-sensitivity C-reactive protein (hs-CRP), TNF- $\alpha$ and IL6 concentrations, while being positively correlated with IL-10 concentrations (Feng et al., 2019). Down-regulation of ZFAS1 could predict risk of LAA strokes. Based on the results of receiver 
TABLE 1 | Human studies showing elevation of IncRNAs in IS.

\begin{tabular}{|c|c|c|c|c|c|c|c|}
\hline IncRNAs & $\begin{array}{l}\text { The specimen } \\
\text { types }\end{array}$ & $\begin{array}{l}\text { Numbers of clinical } \\
\text { specimens }\end{array}$ & Cell models & $\begin{array}{l}\text { Targets/ } \\
\text { Regulators }\end{array}$ & $\begin{array}{l}\text { Signaling } \\
\text { pathways }\end{array}$ & Function & References \\
\hline ANRIL & Blood & $\begin{array}{l}71 \text { IS patients and } 71 \text { normal } \\
\text { controls. }\end{array}$ & - & CDKN2A & - & ANRIL has a role in pathology of IS. & Yang et al., 2018 \\
\hline ANRIL & Serum & $\begin{array}{l}132 \mathrm{AF} \text { patients with IS and } \\
254 \mathrm{AF} \text { without IS }\end{array}$ & - & - & - & Serum ANRIL is a marker in AF with IS. & Zeng and Jin, 2020 \\
\hline GAS5 & Blood & $\begin{array}{l}509 \text { IS patients and } 668 \text { healthy } \\
\text { controls }\end{array}$ & - & - & - & $\begin{array}{l}\text { GAS5 overexpression is associated with } \\
\text { increased IS risk. }\end{array}$ & Zheng et al., 2018 \\
\hline $\mathrm{H} 19$ & & $\begin{array}{l}85 \text { IS patients and } 85 \text { healthy } \\
\text { controls }\end{array}$ & $\begin{array}{l}\text { VSMC and } \\
\text { HUVECs }\end{array}$ & ACP5 & - & $\begin{array}{l}\text { H19 has enhanced ACP5 expression, } \\
\text { increased cell proliferation and blocked cell } \\
\text { apoptosis. }\end{array}$ & Huang et al., 2019 \\
\hline H19 & plasma & $\begin{array}{l}40 \text { patients with acute ischemic } \\
\text { stroke and } 25 \text { controls }\end{array}$ & - & p53 & $\begin{array}{l}\text { p53/Notch1 } \\
\text { pathway }\end{array}$ & $\begin{array}{l}\text { H19 represses neurogenesis following IS } \\
\text { via p53/Notch1 axis. }\end{array}$ & Wang et al., 2019a \\
\hline H19 & $\begin{array}{l}\text { Plasma, } \\
\text { neutrophils, } \\
\text { and } \\
\text { lymphocytes }\end{array}$ & $\begin{array}{l}36 \text { patients with anterior } \\
\text { circulation ischemia, and } 25 \\
\text { normal subjects }\end{array}$ & BV2 cells & HDAC1 & - & H19 induces neuroinflammatory responses. & Wang et al., 2017 \\
\hline KCNQ1OT1 & Blood & $\begin{array}{l}42 \text { IS patients and } 40 \text { healthy } \\
\text { controls }\end{array}$ & $\mathrm{N} 2 \mathrm{a}$ & FOXO3 & $\begin{array}{l}\text { miR-200a/ } \\
\text { FOXO3/ ATG7 } \\
\text { pathway }\end{array}$ & $\begin{array}{l}\text { KCNQ1OT1 expression enhanced brain } \\
\text { injury and induced autophagy in IS. }\end{array}$ & Wang et al., 2019a \\
\hline $\begin{array}{l}\text { linc-SLC22A2, linc-OBP2B-1, } \\
\text { linc_luo_1172 }\end{array}$ & Blood & $\begin{array}{l}133 \text { IS patients and } 133 \\
\text { controls }\end{array}$ & - & - & - & - & $\begin{array}{l}\text { Dykstra-Aiello et al., } \\
2016\end{array}$ \\
\hline $\begin{array}{l}\text { linc-DHFRL1-4, SNHG15 and } \\
\text { linc-FAM98A-3 }\end{array}$ & Blood & $\begin{array}{l}206 \text { IS patients, } 55 \text { TIA patients } \\
\text { and } 179 \text { controls }\end{array}$ & - & - & - & - & Deng et al., 2018 \\
\hline $\begin{array}{l}\text { IncRNA-ENST00000568297, } \\
\text { IncRNA-ENST00000568243, } \\
\text { NR_046084 }\end{array}$ & Blood & 50 IS patients and 50 controls & - & $\begin{array}{l}\text { BCG5, } \\
\text { FOXJ3, } \\
\text { MAP3K5 }\end{array}$ & $\begin{array}{l}\text { PI3K-Akt, p53 } \\
\text { pathway, } \\
\text { AMPK pathway }\end{array}$ & $\begin{array}{l}\text { LncRNA-ENST00000568297 and } \\
\text { IncRNA-ENST00000568243 } \\
\text { Are possible diagnostic biomarkers for IS. }\end{array}$ & Guo et al., 2018 \\
\hline Inc-CRKL-2, Inc-NTRK3-4 & serum & $\begin{array}{l}100 \text { AMS patients and } 100 \\
\text { healthy controls }\end{array}$ & - & - & - & $\begin{array}{l}\text { These new IncRNAs are markers for the } \\
\text { detection of AMS. }\end{array}$ & Xu et al., 2020 \\
\hline MALAT1 & Serum & $\begin{array}{l}40 \mathrm{CIS} \text { patients and } 40 \text { healthy } \\
\text { controls }\end{array}$ & HBMECs & VEGFA & $\begin{array}{l}\text { miR-205- } \\
\text { 5p/NEGFA } \\
\text { Pathway }\end{array}$ & $\begin{array}{l}\text { MALAT1 preserves angiogenic properties of } \\
\text { HBMECs under OGD/R circumstances. }\end{array}$ & Gao et al., 2020 \\
\hline MEG3 & PBMCs & 20 IS patients and 20 controls. & $\begin{array}{l}\text { mouse brain } \\
\text { neuroma cell } \\
\text { line, N2a }\end{array}$ & $\begin{array}{l}\text { miR-424- } \\
5 p \\
\text { Sema3A }\end{array}$ & MAPK & $\begin{array}{l}\text { MEG3 enhances cell survival and } \\
\text { decreased cell apoptosis. }\end{array}$ & Xiang et al., 2020 \\
\hline MIAT & Blood & $\begin{array}{l}189 \text { IS patients and } 189 \text { healthy } \\
\text { controls }\end{array}$ & - & - & - & $\begin{array}{l}\text { MIAT is a biomarker for discriminating IS } \\
\text { patients from healthy persons. }\end{array}$ & Zhu et al., 2018 \\
\hline RMST & plasma & 10 AIS patients and 10 controls & $\begin{array}{l}\text { hippocampal } \\
\text { cells }\end{array}$ & - & - & $\begin{array}{l}\text { RMST induces ischemic brain injury and } \\
\text { disrupts neurological function. }\end{array}$ & $\begin{array}{l}\text { Hou and Cheng, } \\
2018\end{array}$ \\
\hline SCARNA10, TERC, LINC01481 & Blood & 10 IS and 5 controls & - & - & - & $\begin{array}{l}\text { These LncRNAs play an important role in } \\
\text { peripheral immune system changes after IS. }\end{array}$ & Zhu et al., 2019 \\
\hline
\end{tabular}


operating characteristic curve, ZFAS1 has $89.39 \%$ sensitivity in distinguishing LAA stroke patients from controls (Wang et al., 2019b). Another biomarker discovery study in PBMCs of IS patients has demonstrated AUC values of $0.73,0.74$, and 0.69 for ENST00000568297, ENST00000568243 and NR_046084, respectively (Deng et al., 2018). Moreover, MIAT levels in IS patients have been remarkably increased in correlation with NIHSS scores, mRS, hs-CRP and infarct size. Based on the results of ROC (receiver operating characteristic) curves, MIAT has been suggested as a possible marker for distinguishing IS patients from the healthy subjects with AUC value of 0.842 . Moreover, patients with over-expression of MIAT had a comparatively poor prognosis. Multivariate analysis has shown the potential of MIAT as an independent prognostic biomarker of functional outcome and mortality of IS (Zhu et al., 2018). Table 3 gives a brief review of investigations that reported diagnostic/prognostic role of lncRNAs in IS.

\section{MicroRNAs and Stroke}

Expression of miR-205-5p has been surged in the serum specimens of CIS patients and human brain microvascular endothelial cells under oxygen glucose deprivation/reoxygenation. Besides, this condition has interfered with the tube formation of human brain microvascular endothelial cells. miR-205-5p knock-down has enhanced proliferation and angiogenic capacity of endothelial cells to resist oxygen glucose deprivation/re-oxygenation injury (Gao et al., 2020). The relationship between upper limb recovery after IS and miRNA signature has been assessed by another group. Authors have discovered lower levels of miR-371-3p, miR-524, miR520g, miR-1255A, miR-453, and miR-583, while upper levels of miR-941, miR-449b, and miR-581 in good recover group compared with poor recovery group. These miRNAs have been shown to congregate on pathways related with axon guidance, developmental processes and carcinogenesis (Edwardson et al., 2018b). Expression of let-7e-5p has also been shown to be elevated in IS patients compared with control subjects. Over-expression of let-7e-5p has been associated with elevated probability of IS. This miRNA has been suggested to influence expression of four genes enriched in the MAPK pathway including CASP3 and NLK (Huang et al., 2016). miRNA levels might also distinguish IS patients from those with hemorrhagic stroke (HS). Leung et al. have demonstrated higher median plasma levels of miR-124-3p in acute phase of HS patients compared with similar phase of IS, while miR-16 had the opposite trend. Both miRNAs have been suggested as diagnostic markers for discrimination of HS from IS (Leung et al., 2014). A high throughput miRNA profiling in IS has reported differential expression of 115 miRNAs between IS cases and healthy controls. These transcripts have been linked with axon guidance, glioma, MAPK, mTOR and Erb-B signaling pathways. miR-32-3p, miR-106-5p, and miR-532-5p have been the first ranked ones (Li et al., 2015). Table 4 provides the summary of researches which reported elevation of miRNAs in IS.

Blood amounts of miR-30a and miR-126 have been substantially decreased in all assessed patients with IS until 24 weeks. Circulating let-7b has been decreased in patients 
TABLE 3 | Diagnostic/prognostic role of IncRNAs in stroke.

\begin{tabular}{|c|c|c|c|c|c|c|c|}
\hline Samples & Area under curve & Sensitivity & Specificity & Kaplan-Meier analysis & $\begin{array}{l}\text { Univariate cox } \\
\text { regression }\end{array}$ & $\begin{array}{l}\text { Multivariate cox } \\
\text { regression }\end{array}$ & References \\
\hline $\begin{array}{l}\text { Blood specimens from } 126 \text { AIS } \\
\text { patients and } 125 \text { controls }\end{array}$ & 0.759 for ANRIL & $72.2 \%$ for ANRIL & $71.2 \%$ for ANRIL & - & - & - & $\begin{array}{l}\text { Feng et al., } \\
2019\end{array}$ \\
\hline $\begin{array}{l}\text { Blood specimens from } 206 \\
\text { Ischemic stroke patients in the } \\
\text { acute phase, } 55 \text { transient } \\
\text { ischemic attack patients and } \\
179 \text { healthy controls }\end{array}$ & $\begin{array}{l}0.711 \text { for } \\
\text { linc-DHFRL1-4, } 0.756 \\
\text { for SNHG15, 0.659 for } \\
\text { linc-FAM98A-3 }\end{array}$ & $\begin{array}{l}0.687 \text { for linc-DHFRL1-4, } 0.594 \\
\text { for SNHG15, } 0.594 \text { for } \\
\text { linc-FAM98A-3 }\end{array}$ & $\begin{array}{l}0.719 \text { for } \\
\text { linc-DHFRL1-4, } 0.844 \\
\text { for SNHG15, 0.688 for } \\
\text { linc-FAM98A-3 }\end{array}$ & - & - & - & $\begin{array}{l}\text { Deng et al., } \\
2018\end{array}$ \\
\hline $\begin{array}{l}\text { Blood specimens from } 50 \\
\text { patients with IS and } 50 \text { controls }\end{array}$ & $\begin{array}{l}0.733 \text { for } \\
\text { ENST00000568297, } \\
0.743 \text { for } \\
\text { ENST00000568243, } \\
0.690 \text { for NR_046084 }\end{array}$ & $\begin{array}{l}64.8 \% \text { for ENST00000568297, } \\
70.5 \% \text { for ENST00000568243, } \\
61.5 \% \text { for NR_046084 }\end{array}$ & $\begin{array}{l}63.6 \% \text { for } \\
\text { ENST00000568297, } \\
69.5 \% \text { for } \\
\text { ENST00000568243, } \\
\text { 69.2\% for NR_046084 }\end{array}$ & - & - & - & $\begin{array}{l}\text { Guo et al., } \\
2018\end{array}$ \\
\hline $\begin{array}{l}176 \text { IS patients and } 111 \\
\text { controls }\end{array}$ & 0.727 for ZFAS1 & 89.39 for ZFAS1 & 48.65 for ZFAS1 & - & - & $\begin{array}{l}\text { ZFAS1 low expression } \\
\text { was associated with } \\
\text { risk of LAA strokes. }\end{array}$ & $\begin{array}{l}\text { Wang et al., } \\
2019 b\end{array}$ \\
\hline $\begin{array}{l}\text { Blood specimens from } 71 \text { IS } \\
\text { patients and } 71 \text { normal } \\
\text { controls. }\end{array}$ & 0.642 for ANRIL & 0.663 for ANRIL & 0.538 for ANRIL & - & - & - & $\begin{array}{l}\text { Yang et al., } \\
2018\end{array}$ \\
\hline $\begin{array}{l}\text { Blood specimens from } 189 \text { IS } \\
\text { patients and } 189 \text { healthy } \\
\text { controls }\end{array}$ & 0.842 for MIAT & $74.1 \%$ for MIAT & $80.4 \%$ for MIAT & $\begin{array}{l}\text { Patients with } \\
\text { over-expression of MIAT } \\
\text { had a higher mortality } \\
\text { compared with the } \\
\text { low-MIAT patients. } \\
\text { High MIAT was associated } \\
\text { with poor prognosis. }\end{array}$ & $\begin{array}{l}\text { Elevated MIAT } \\
\text { Has been associated } \\
\text { with IS. }\end{array}$ & $\begin{array}{l}\text { MIAT was an } \\
\text { independent prognostic } \\
\text { indicator of functional } \\
\text { consequences and } \\
\text { mortality. }\end{array}$ & Zhu et al., 2018 \\
\hline $\begin{array}{l}\text { Serum specimens from } 132 \mathrm{AF} \\
\text { patients with IS and } 254 \mathrm{AF} \\
\text { without IS }\end{array}$ & 0.826 for ANRIL & $76.6 \%$ for ANRIL & $81.4 \%$ for ANRIL & $\begin{array}{l}\text { Patients with lower IncRNA } \\
\text { ANRIL expression had } \\
\text { higher relapse-free survival } \\
\text { compared with the } \\
\text { high-expression group. }\end{array}$ & $\begin{array}{l}\text { Serum ANRIL } \\
\text { expression, NIHSS } \\
\text { score, infarct size, and } \\
\text { smoking were the risk } \\
\text { factors for AF with IS. }\end{array}$ & $\begin{array}{l}\text { Serum ANRIL } \\
\text { expression and } \\
\text { smoking were } \\
\text { independent risk } \\
\text { factors for AF with IS. }\end{array}$ & $\begin{array}{l}\text { Zeng and Jin, } \\
2020\end{array}$ \\
\hline
\end{tabular}


TABLE 4 | Summary of human studies reporting elevation of miRNAs in IS.

\begin{tabular}{|c|c|c|c|c|c|c|c|}
\hline microRNA & $\begin{array}{l}\text { The specimen } \\
\text { types }\end{array}$ & $\begin{array}{l}\text { Numbers of clinical } \\
\text { specimens }\end{array}$ & Cells & $\begin{array}{l}\text { Targets/ } \\
\text { Regulators }\end{array}$ & $\begin{array}{l}\text { Signaling } \\
\text { pathways }\end{array}$ & Function & References \\
\hline let-7e-5p & Blood & $\begin{array}{l}302 \text { IS patients and } 302 \text { healthy } \\
\text { controls }\end{array}$ & U937 cell line & $\begin{array}{l}\text { CASP3 and } \\
\text { NLK }\end{array}$ & $\begin{array}{l}\text { MAPK signaling } \\
\text { pathway }\end{array}$ & $\begin{array}{l}\text { Let-7e-5p might be a useful noninvasive } \\
\text { marker for the diagnosis of IS. }\end{array}$ & Huang et al., 2016 \\
\hline $\operatorname{miR}-145$ & Blood & $\begin{array}{l}32 \text { IS patients and } 18 \text { healthy } \\
\text { controls }\end{array}$ & - & $\mathrm{KLF} 4 / 5$ & - & $\begin{array}{l}\text { MiR-145 might serve as a useful biomarker } \\
\text { and therapy for IS. }\end{array}$ & Gan et al., 2012 \\
\hline miR-363, miR-487b & Blood & 24 AIS patients and 24 control & - & MAP2K4 & $\begin{array}{l}\text { toll-like receptor } \\
\text { signaling } \\
\text { pathway }\end{array}$ & $\begin{array}{l}\text { These miRNA may regulate leukocyte gene } \\
\text { expression. }\end{array}$ & Jickling et al., 2014 \\
\hline $\begin{array}{l}\text { miR-125b-2, miR-27a, } \\
\text { miR-422a, miR-488 and } \\
\text { miR-627 }\end{array}$ & Blood & $\begin{array}{l}169 \text { stroke patients, } 24 \text { healthy } \\
\text { controls, and } 94 \text { individuals } \\
\text { with metabolic syndrome }\end{array}$ & - & - & - & $\begin{array}{l}\text { These miRNAs may serve as potential } \\
\text { diagnostic biomarkers for IS. }\end{array}$ & $\begin{array}{l}\text { Sepramaniam } \\
\text { et al., } 2014\end{array}$ \\
\hline $\begin{array}{l}\text { miR-9-5p, miR-9-3p, miR-107, } \\
\text { miR-124-3p, and miR-128-3p }\end{array}$ & CSF & 21 IS patients and 21 controls & - & - & - & $\begin{array}{l}\text { These miRNAs show the ischemia-related } \\
\text { brain damage. }\end{array}$ & $\begin{array}{l}\text { Sørensen et al., } \\
2017\end{array}$ \\
\hline $\begin{array}{l}\text { miR-17-5p, miR-20b-5p, } \\
\text { miR-27b-3p, miR-93-5p }\end{array}$ & $\begin{array}{l}\text { Extracellular } \\
\text { Vesicle in blood }\end{array}$ & $\begin{array}{l}34 \text { non-stroke and } 139 \text { stroke } \\
\text { patients }\end{array}$ & - & - & $\begin{array}{l}\text { stress/hypoxia } \\
\text { and repair } \\
\text { pathways }\end{array}$ & $\begin{array}{l}\text { These miRNAs profile shows the } \\
\text { development of cerebral SVD. }\end{array}$ & $\begin{array}{l}\text { van Kralingen et al., } \\
2019\end{array}$ \\
\hline $\begin{array}{l}\text { hsa-miR-4656, hsa-miR-432, } \\
\text { hsa-miR-503, hsa-miR-376c, } \\
\text { hsa-miR-130a-3p and } \\
\text { hsa-miR-487b }\end{array}$ & PBMCs & $\begin{array}{l}20 \text { IS patients and } 19 \text { healthy } \\
\text { controls }\end{array}$ & - & $\begin{array}{l}\text { TGFB3, } \\
\text { CELSR2 } \\
\text { and ITM2C }\end{array}$ & - & These miRNAs regulate immune responses. & Bam et al., 2018 \\
\hline let-7b & Plasma & 197 IS patients and 50 controls & - & - & - & $\begin{array}{l}\text { Let-7b might serve as a useful noninvasive } \\
\text { marker for the diagnosis of IS. }\end{array}$ & Long et al., 2013 \\
\hline miR-124-3p and miR-16 & Plasma & $74 \mathrm{IS}$ and $19 \mathrm{HS}$ & - & - & - & $\begin{array}{l}\text { miR-124-3p and miR-16 Expression levels } \\
\text { may be the potential circulating biomarker } \\
\text { to distinguish hemorrhagic stroke and IS. }\end{array}$ & Leung et al., 2014 \\
\hline $\begin{array}{l}\text { miR-222, miR-218, and } \\
\text { miR-185 }\end{array}$ & Plasma & $\begin{array}{l}106 \text { AIS patients and } 110 \\
\text { controls }\end{array}$ & - & - & - & $\begin{array}{l}\text { These miRNAs might serve as promising } \\
\text { and independent biomarkers for risk of AlS. }\end{array}$ & Jin and Xing, 2017 \\
\hline $\begin{array}{l}\text { hsa-miR-106b-5P, } \\
\text { hsa-miR-4306 }\end{array}$ & Plasma & $\begin{array}{l}136 \text { AIS patients and } 116 \\
\text { healthy controls }\end{array}$ & - & - & - & $\begin{array}{l}\text { Enhanced expression of hsa-miR-106b-5P } \\
\text { and hsa-miR- } 4306 \text { in plasma may be novel } \\
\text { biomarkers for the early detection of AIS. }\end{array}$ & Wang et al., 2014 \\
\hline miR-16 & Plasma & $\begin{array}{l}40 \mathrm{HACl} \text { patients and } 30 \\
\text { healthy controls. }\end{array}$ & - & - & - & $\begin{array}{l}\text { The high expression of miR-16 in plasma } \\
\text { were related to TOAST and OCSP criteria. }\end{array}$ & Tian et al., 2016 \\
\hline $\begin{array}{l}\text { miR-143-3p, miR-125b-5p, } \\
\text { miR-125a-5p }\end{array}$ & Plasma & $\begin{array}{l}200 \text { IS patients and } 100 \text { healthy } \\
\text { controls }\end{array}$ & - & - & - & $\begin{array}{l}\text { A combination of miR-125a-5p, } \\
\text { miR-125b-5p, and miR-143-3p might have } \\
\text { clinical utility as an early diagnostic } \\
\text { biomarker. }\end{array}$ & Tiedt et al., 2017 \\
\hline miR-125b-5p and miR-206 & Plasma & $\begin{array}{l}94 \text { AIS patients with or without } \\
\text { endovascular treatment }\end{array}$ & - & - & - & $\begin{array}{l}\text { miR-125b-5p and miR-206 levels are } \\
\text { related with stroke severity. }\end{array}$ & $\begin{array}{l}\text { van Kralingen et al., } \\
2019\end{array}$ \\
\hline miR-371-3p and miR-520g & Plasma & 27 IS patients & - & - & - & These miRNAs are markers of neural repair. & $\begin{array}{l}\text { Edwardson et al., } \\
2018 \text { a }\end{array}$ \\
\hline
\end{tabular}


TABLE 4 | (Continued)

\begin{tabular}{|c|c|c|c|c|c|c|c|}
\hline microRNA & $\begin{array}{l}\text { The specimen } \\
\text { types }\end{array}$ & $\begin{array}{l}\text { Numbers of clinical } \\
\text { specimens }\end{array}$ & Cells & $\begin{array}{l}\text { Targets/ } \\
\text { Regulators }\end{array}$ & $\begin{array}{l}\text { Signaling } \\
\text { pathways }\end{array}$ & Function & References \\
\hline$m i R-205-5 p$ & Serum & $\begin{array}{l}40 \mathrm{CIS} \text { patients and } 40 \text { healthy } \\
\text { controls }\end{array}$ & HBMECs & MALAT1 & - & $\begin{array}{l}\text { miR-205-5p inhibits proliferation of } \\
\text { endothelial cells. }\end{array}$ & Gao et al., 2020 \\
\hline $\begin{array}{l}\text { miR-15a, miR-16, and } \\
\text { miR-17-5p }\end{array}$ & Serum & $\begin{array}{l}106 \text { AlS patients and } 120 \\
\text { healthy controls }\end{array}$ & - & - & - & $\begin{array}{l}\text { Combination of miR- } 15 a \text {, miR- } 16 \text {, and } \\
\text { miR-17-5p may be a potential AIS } \\
\text { biomarker. }\end{array}$ & Wu et al., 2015 \\
\hline$m i R-15 a$ and miR-16 & Serum & $\begin{array}{l}20 \text { CLI patients, } 122 \mathrm{~T} 2 \mathrm{D}+\mathrm{CLI} \\
\text { patients, and } 43 \text { healthy } \\
\text { controls }\end{array}$ & $\begin{array}{l}\text { Circulating } \\
\text { proangiogenic } \\
\text { cells (PACs), } \\
\text { VSMCs, and } \\
\text { pericytes }\end{array}$ & $\begin{array}{l}\text { VEGF-A } \\
\text { and AKT3 }\end{array}$ & $\begin{array}{l}\text { AKT signaling } \\
\text { pathway }\end{array}$ & $\begin{array}{l}\text { miR-15a/16 induces PAC survival and } \\
\text { migration, and increases migratory capacity } \\
\text { of PACs }\end{array}$ & Spinetti et al., 2013 \\
\hline $\operatorname{miR}-145$ & Serum & 146 AIS patients and 96 control & - & - & - & $\begin{array}{l}\text { MiR- } 145 \text { might serve as a useful biomarker } \\
\text { and therapy for IS. }\end{array}$ & Jia et al., 2015 \\
\hline miR-9 and miR-124 & Serum & 65 AlS patients and 66 control & - & - & - & $\begin{array}{l}\text { Serum exosomal miR-9 and miR-124 are } \\
\text { markers for AIS. }\end{array}$ & Ji et al., 2016 \\
\hline $\operatorname{miR}-223$ & Serum & 50 AlS patients and 33 control & - & - & - & $\begin{array}{l}\text { Exosomal miR-223 levels are associated } \\
\text { with acute IS. }\end{array}$ & Chen et al., 2017 \\
\hline miR-146b & Serum & $\begin{array}{l}128 \text { AIS patients and } 102 \\
\text { control }\end{array}$ & - & - & - & $\begin{array}{l}\text { Elevated serum miR-146b expression might } \\
\text { be a potential biomarker for AIS evaluation. }\end{array}$ & Chen et al., 2018b \\
\hline $\begin{array}{l}\text { miR32-3p, miR-106b-5p, } \\
\text { miR-423-5p, miR-451a, } \\
\text { miR-1246, miR-1299, } \\
\text { miR-3149, and miR-4739 }\end{array}$ & Serum & $\begin{array}{l}117 \text { AIS patients and } 82 \\
\text { healthy controls }\end{array}$ & - & - & - & $\begin{array}{l}\text { These miRNAs may serve as potential } \\
\text { diagnostic biomarkers for IS. }\end{array}$ & Li et al., 2015 \\
\hline $\begin{array}{l}\text { miR-23b-3p, miR-29b-3p, } \\
\text { miR-181a-5p and miR-21-5p }\end{array}$ & Serum & $\begin{array}{l}177 \text { IS, } 81 \text { TIA patients and } 42 \\
\text { controls. }\end{array}$ & - & - & - & $\begin{array}{l}\text { Enhanced expression of miR-23b-3p, } \\
\text { miR-29b-3p and miR-21-5p might } \\
\text { distinguish between IS and TIA. }\end{array}$ & Wu et al., 2017 \\
\hline $\begin{array}{l}\text { PC-3p-57664, PC-5p-12969, } \\
\text { hsa-miR-122-5p and } \\
\text { hsa-miR-211-5p }\end{array}$ & Serum & $\begin{array}{l}34 \text { IS patients and } 11 \text { healthy } \\
\text { controls. postmortem } \\
\text { specimens from } 10 \text { IS brains } \\
\text { and } 10 \text { control brains }\end{array}$ & $\begin{array}{l}\text { lymphoblastoid } \\
\text { cell line }\end{array}$ & - & - & These miRNAs are biomarkers for IS. & Vijayan et al., 2018 \\
\hline let-7e & $\begin{array}{l}\text { serum and } \\
\text { cerebral spinal } \\
\text { fluid }\end{array}$ & $\begin{array}{l}72 \text { IS patients and } 51 \text { healthy } \\
\text { controls }\end{array}$ & - & - & - & $\begin{array}{l}\text { let-7e Expression levels in serum may be } \\
\text { the potential circulating biomarker for the } \\
\text { acute stage of ischemic stroke. }\end{array}$ & Peng et al., 2015 \\
\hline
\end{tabular}


TABLE 5 | Summary of human studies reporting down-regulation of miRNAs in IS.

\begin{tabular}{|c|c|c|c|c|c|c|c|}
\hline microRNA & $\begin{array}{l}\text { The specimen } \\
\text { types }\end{array}$ & $\begin{array}{l}\text { Numbers of clinical } \\
\text { specimens }\end{array}$ & Cell line & $\begin{array}{l}\text { Targets/ } \\
\text { Regulators }\end{array}$ & $\begin{array}{l}\text { Signaling } \\
\text { pathways }\end{array}$ & Function & References \\
\hline miR-145 & & - & $\begin{array}{l}\text { Primary } \\
\text { astrocytes from } \\
\text { rats }\end{array}$ & AQP4 & - & miR-145 protects astrocytes from damage. & Zheng et al., 2017 \\
\hline $\begin{array}{l}\text { miR-122, miR-148a, let-7i, } \\
\text { miR-19a, miR-320d, miR-4429 }\end{array}$ & Blood & 24 AIS patients and 24 control & - & $\begin{array}{l}\text { GFR, RAS, } \\
\text { PI3K, AKT, } \\
\text { IKK }\end{array}$ & NF-к $\beta$ signaling & $\begin{array}{l}\text { These miRNA may regulate leukocyte gene } \\
\text { expression in IS. }\end{array}$ & Jickling et al., 2014 \\
\hline miR-574-3p & Blood & $\begin{array}{l}55 \text { chronic stroke patients and } \\
2360 \text { controls }\end{array}$ & - & $\begin{array}{l}\text { DBNDD2 } \\
\text { and } \\
\text { ELOVL1 }\end{array}$ & $\begin{array}{l}\text { neurometabolic } \\
\text { and chronic } \\
\text { neuronal injury } \\
\text { response } \\
\text { pathways }\end{array}$ & $\begin{array}{l}\text { miR-574-3p has a role in regulating chronic } \\
\text { brain and systemic cellular response to } \\
\text { stroke }\end{array}$ & Salinas et al., 2019 \\
\hline miRNA-660-5p & $\begin{array}{l}\text { Extracellular } \\
\text { Vesicle in blood }\end{array}$ & $\begin{array}{l}34 \text { non-stroke and } 139 \text { stroke } \\
\text { patients }\end{array}$ & - & - & - & $\begin{array}{l}\text { This miRNA associated with } \\
\text { pathophysiology of IS }\end{array}$ & $\begin{array}{l}\text { van Kralingen et al., } \\
2019\end{array}$ \\
\hline hsa-miR-874-3p & PBMCs & $\begin{array}{l}20 \text { IS patients and } 19 \text { healthy } \\
\text { controls }\end{array}$ & - & $\begin{array}{l}\text { IL12A and } \\
\text { IL12B }\end{array}$ & - & $\begin{array}{l}\text { hsa-miR-874-3p involves in the immune } \\
\text { system alteration during IS pathophysiology }\end{array}$ & Bam et al., 2018 \\
\hline miR-30a and miR-126 & Plasma & 197 IS patients and 50 controls & - & - & - & miR-30a and miR-126 are markers of IS. & Long et al., 2013 \\
\hline $\begin{array}{l}\text { miR-126, miR-130a, and } \\
\text { miR-378 }\end{array}$ & Plasma & $\begin{array}{l}106 \text { AIS patients and } 110 \\
\text { controls }\end{array}$ & - & - & - & $\begin{array}{l}\text { These miRNAs might serve as promising } \\
\text { and independent biomarkers for risk of AIS. }\end{array}$ & Jin and Xing, 2017 \\
\hline hsa-miR-320e, hsa-miR-320d & Plasma & $\begin{array}{l}136 \text { AIS patients and } 116 \\
\text { healthy controls }\end{array}$ & - & - & - & $\begin{array}{l}\text { Reduced expression of hsa-miR-320e and } \\
\text { hsa-miR-320d is marker for early detection } \\
\text { of AlS. }\end{array}$ & Wang et al., 2014 \\
\hline let-7i-3p and miR-23a-3p & Plasma & $\begin{array}{l}10 \text { AIS patients and } 10 \text { healthy } \\
\text { controls }\end{array}$ & - & - & - & $\begin{array}{l}\text { These miRNAs associated with the } \\
\text { peculiarities of clinical manifestations of IS }\end{array}$ & Zhanin et al., 2018 \\
\hline miR-195 & Plasma & 96 AIS patients & $\begin{array}{l}\text { C57BL/6 mice, } \\
\text { BV2 microglial } \\
\text { cells and } \\
\text { HEK293T cells }\end{array}$ & $\begin{array}{l}\text { CX3CL1 } \\
\text { and } \\
\text { CX3CR1 }\end{array}$ & $\begin{array}{l}\text { CX3CL1/CX3CR1 } \\
\text { signaling } \\
\text { pathway }\end{array}$ & miR-195 has neuroprotective roles. & Guang et al., 2019 \\
\hline $\begin{array}{l}\text { miR-449b, miR-519b, } \\
\text { miR-581, miR-616, miR-892b, } \\
\text { miR-941, miR-1179, miR-1292, } \\
\text { and miR-1296 }\end{array}$ & Plasma & 27 IS patients & - & - & - & These miRNAs show neural repair. & $\begin{array}{l}\text { Edwardson et al., } \\
\text { 2018a }\end{array}$ \\
\hline miR23a and miR-221 & Serum & 146 AIS patients and 96 control & - & - & - & & Jia et al., 2015 \\
\hline miR-124, miR-9 & Serum & 31 AIS patients and 11 control & - & MMP-9 & - & $\begin{array}{l}\text { Serum miR-124, miR-9 inhibit } \\
\text { neuroinflammation and brain injury. }\end{array}$ & Liu et al., 2015 \\
\hline
\end{tabular}




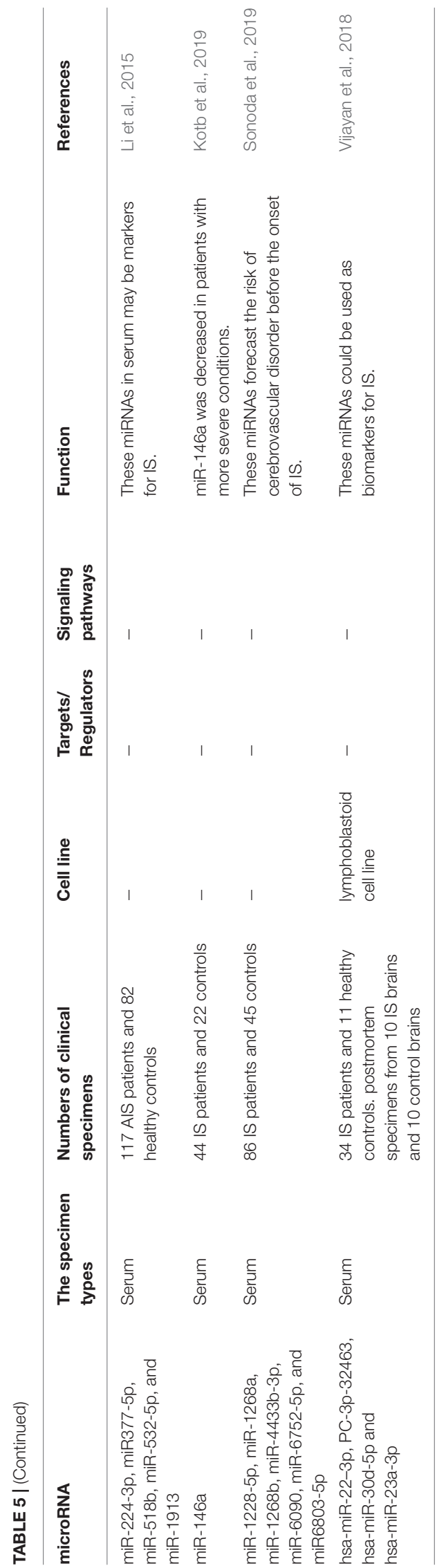

with LAA compared with healthy subjects, while circulating let-7b have been higher in patients with other kinds of IS until 24 weeks. Notably, aberrant miRNAs levels have been resolved 48 weeks after IS onset in all patients. Authors have suggested that miR-30a might affect IS through modulation of RhoB and beclin-1. Moreover, miR-126 and let-7 can contribute in this process through modulation of VCAM-1 and inflammatory responses, respectively (Long et al., 2013). Another investigation has demonstrated that miRNA signature reveal not only the chronological development of IS but also the specific reasons for development of IS. Authors have suggested a 32-miRNA panel that can distinguish stroke etiologies during the acute phase. Moreover, miR-125b-2*, miR-27a*, miR-422a, miR-488, and miR-627 have been constantly dysregulated in acute stroke independent of age or severity or underlying metabolic background (Sepramaniam et al., 2014). Table 5 provides outcome of human studies reporting down-regulation of miRNAs in IS.

Diagnostic and prognostic role of miRNAs have been appraised in IS. Elevated serum amounts of miR-15a, miR-16, and miR-17-5p in acute IS patients could be used as diagnostic markers. Based on the multivariate logistic regression analysis, serum miR-17-5p levels could discriminate the presence of acute IS. miR-15a, miR-16, and miR-17-5p had AUC values of 0.698, 0.82 , and 0.784 , respectively. Combination of three miRNAs increased the AUC value to 0.845 (Wu et al., 2015). ROC curve analysis has revealed AUC values of $0.91,0.91,0.92$, and 0.93 for plasma miR-30a levels, at $24 \mathrm{~h}, 1,4$, and 24 weeks, respectively. These values have been $0.93,0.92,0.92$, and 0.91 for miR-126 at these time points, respectively. Taken together, miR-30a, miR-126 and let-7b can be suitable biomarkers for IS (Long et al., 2013). Expression levels of miR-145 and miR-210 have been remarkably elevated in IS patients with robust AUC values of 0.90 and 1.0, respectively. Yet, dysregulation of miR-145 and miR-210 has not been exclusive for the acute phase as they have been also upregulated in recovery phase (Sepramaniam et al., 2014). Table 6 provides summary of studies reporting diagnostic/prognostic role of miRNAs in IS.

\section{Animal Studies}

Investigations in animal models of IS have provided valuable data about the mechanisms of involvement of IncRNAs/miRNAs in IS and possible application of targeted therapies against these transcripts. For instance, expression of RMST has been elevated in primary hippocampal neurons exposed with oxygenglucose deprivation and in animal models of IS induced by middle cerebral artery occlusion (MCAO). RMST silencing has amended brain injury in the mentioned animal model and attenuated hippocampal neuron defects (Hou and Cheng, 2018). H19 is another up-regulated lncRNA in animal models of IS whose silencing has diminished the size of brain tissue damage following middle cerebral artery obstruction and reperfusion and ameliorated the neurological defects. Mechanistically, H19 silencing could reduce expression of neurogenesis related proteins. Taken together, H19 precludes the development of neurogenesis after IS via p53/Notch1 pathway (Wang et al., 2019a). A throughput miRNA sequencing in infarcted brain 
TABLE 6 | Diagnostic/prognostic role of miRNAs in IS.

\begin{tabular}{|c|c|c|c|c|c|c|c|}
\hline Sample number & Area under curve & Sensitivity & Specificity & $\begin{array}{l}\text { Kaplan-Meier } \\
\text { analysis }\end{array}$ & $\begin{array}{l}\text { Univariate cox } \\
\text { regression }\end{array}$ & Multivariate cox regression & References \\
\hline $\begin{array}{l}\text { Plasma specimens from } 197 \text { IS } \\
\text { patients and } 50 \text { controls }\end{array}$ & $\begin{array}{l}0.91 \text { for miR-30 } \\
0.92 \text { for miR-126 } \\
0.93 \text { for let- } 7 b\end{array}$ & $\begin{array}{l}80 \% \text { for miR- } 30 \\
84 \% \text { for miR- } 126 \\
84 \% \text { for let- } 7 b\end{array}$ & $\begin{array}{l}94 \% \text { for miR-30, } \\
92 \% \text { for miR- } 126 \\
92 \% \text { for let- } 7 b\end{array}$ & - & - & - & Long et al., 2013 \\
\hline $\begin{array}{l}\text { serum and cerebral spinal fluid } \\
\text { specimens from } 72 \text { IS patients } \\
\text { and } 51 \text { healthy controls }\end{array}$ & 0.86 for let- $7 e$ & $82.8 \%$ & $73.4 \%$ & - & - & - & Peng et al., 2015 \\
\hline $\begin{array}{l}\text { Blood specimens from } 302 \text { IS } \\
\text { patients and } 302 \text { healthy } \\
\text { controls }\end{array}$ & 0.82 for let- $-7 e-5 p$ & - & - & - & - & - & Huang et al., 2016 \\
\hline $\begin{array}{l}\text { Serum specimens from } 106 \text { AIS } \\
\text { patients and } 120 \text { healthy } \\
\text { controls }\end{array}$ & $\begin{array}{l}0.698 \text { for miR-15a, } 0.82 \text { for } \\
\text { miR-16, and } 0.784 \text { for } \\
\text { miR-17-5p }\end{array}$ & - & - & - & - & $\begin{array}{l}\text { Serum miR-17-5p is an } \\
\text { independent marker for AIS. }\end{array}$ & Wu et al., 2015 \\
\hline $\begin{array}{l}\text { Plasma specimens from } 74 \text { IS } \\
\text { and } 19 \mathrm{HS}\end{array}$ & $\begin{array}{l}0.70 \text { for miR-124-3p, } \\
0.59 \text { for miR-16 }\end{array}$ & $\begin{array}{l}68.4 \% \text { for } \\
\text { miR-124-3p, } \\
94.7 \% \text { for miR-16 }\end{array}$ & $\begin{array}{l}71.2 \% \text { for miR-124-3p, } \\
35.1 \% \text { for miR-16 }\end{array}$ & - & - & $\begin{array}{l}\text { NIHSS, platelet count and the } \\
\text { plasma levels of miR-124-3p } \\
\text { were significant predictors of HS. }\end{array}$ & Leung et al., 2014 \\
\hline $\begin{array}{l}\text { Plasma specimens from } 106 \\
\text { AlS patients and } 110 \text { controls }\end{array}$ & 0.767 for combined miRNAs & $\begin{array}{l}87.7 \% \text { for } \\
\text { combined miRNAs }\end{array}$ & $\begin{array}{l}54.5 \% \text { for combined } \\
\text { miRNAs }\end{array}$ & - & $\begin{array}{l}\text { miR-126, miR-130a, } \\
\text { miR-378, miR-222, } \\
\text { miR-218, and miR-185 } \\
\text { were predicting factors } \\
\text { for risk of AlS. }\end{array}$ & $\begin{array}{l}\text { miR-126 and miR-130a were } \\
\text { protective factors for AlS. } \\
\text { miR-222, miR-218, and miR-185 } \\
\text { were risk factors for AIS. }\end{array}$ & Jin and Xing, 2017 \\
\hline $\begin{array}{l}\text { Serum specimens from } 146 \text { AIS } \\
\text { patients and } 96 \text { control }\end{array}$ & $\begin{array}{l}0.896 \text { for miR-145, } \\
0.816 \text { for miR-23a, } \\
0.819 \text { for miR-221 }\end{array}$ & - & - & - & - & - & Jia et al., 2015 \\
\hline $\begin{array}{l}\text { Serum specimens from } 65 \text { AIS } \\
\text { patients and } 66 \text { control }\end{array}$ & $\begin{array}{l}0.8026 \text { for miR- } 9 \text {, } \\
0.6976 \text { for miR-124 }\end{array}$ & - & - & - & - & - & Ji et al., 2016 \\
\hline $\begin{array}{l}\text { Serum specimens from } 50 \text { AIS } \\
\text { patients and } 33 \text { control }\end{array}$ & 0.859 for miR-223 & $84.0 \%$ for miR-223 & $78.8 \%$ for miR-223 & - & - & $\begin{array}{l}\text { Circulating exosomal miR-223 is } \\
\text { risk factor for IS. }\end{array}$ & Chen et al., 2017 \\
\hline $\begin{array}{l}\text { Serum specimens from } 128 \text { AIS } \\
\text { patients and } 102 \text { control }\end{array}$ & $\begin{array}{l}0.863 \text { for combination of } \\
\text { hs-CRP and miR-146b }\end{array}$ & - & - & - & - & - & Chen et al., 2018b \\
\hline $\begin{array}{l}\text { Blood specimens from } 169 \\
\text { stroke patients, } 24 \text { healthy } \\
\text { controls, and } 94 \text { individuals } \\
\text { with metabolic syndrome }\end{array}$ & $\begin{array}{l}0.95 \text { for miR-125b-2, } \\
0.89 \text { for miR-27a, } \\
0.92 \text { for miR-422a, } \\
0.87 \text { for miR-488, } \\
0.84 \text { for miR-627 }\end{array}$ & - & - & - & - & - & $\begin{array}{l}\text { Sepramaniam } \\
\text { et al., } 2014\end{array}$ \\
\hline
\end{tabular}


TABLE 6 | (Continued)

\begin{tabular}{|c|c|c|c|c|c|c|c|}
\hline Sample number & Area under curve & Sensitivity & Specificity & $\begin{array}{l}\text { Kaplan-Meier } \\
\text { analysis }\end{array}$ & $\begin{array}{l}\text { Univariate cox } \\
\text { regression }\end{array}$ & Multivariate cox regression & References \\
\hline $\begin{array}{l}\text { Plasma specimens from } 136 \\
\text { AlS patients and } 116 \text { healthy } \\
\text { controls }\end{array}$ & $\begin{array}{l}0.962 \text { for hsa-miR-106b-5P; } \\
0.952 \text { for hsa-miR-4306; } \\
0.981 \text { for hsa-miR-320e; } \\
0.987 \text { for hsa-miR-320d }\end{array}$ & - & - & - & - & - & Wang et al., 2014 \\
\hline $\begin{array}{l}\text { Plasma specimens from } 40 \\
\text { HACl patients and } 30 \text { healthy } \\
\text { controls. }\end{array}$ & 0.775 for miR- 16 & $69.7 \%$ for miR-16 & $87 \%$ for miR-16 & - & - & $\begin{array}{l}\text { Patients with higher expression of } \\
\text { MiR-16 were associated with } \\
\text { poor prognosis. }\end{array}$ & Tian et al., 2016 \\
\hline $\begin{array}{l}\text { Plasma specimens from } 200 \text { IS } \\
\text { patients and } 100 \text { healthy } \\
\text { controls. }\end{array}$ & $\begin{array}{l}0.93 \text { for combination of } \\
\text { miR-143-3p, miR-125b-5p, } \\
\text { and miR-125a-5p }\end{array}$ & $\begin{array}{l}85.6 \% \text { for } \\
\text { combination of } \\
\text { miR-143-3p, } \\
\text { miR-125b-5p, and } \\
\text { miR-125a-5p }\end{array}$ & $\begin{array}{l}76.3 \% \text { for combination } \\
\text { of miR-143-3p, } \\
\text { miR-125b-5p, and } \\
\text { miR-125a-5p }\end{array}$ & - & - & - & Tiedt et al., 2017 \\
\hline $\begin{array}{l}\text { Serum specimens from } 177 \text { IS, } \\
81 \text { TIA patients and } 42 \text { controls. }\end{array}$ & $\begin{array}{l}0.883 \text { for combination of } \\
\text { miR-23b-3p, miR-29b-3p, } \\
\text { miR-181a-5p and miR-21-5p }\end{array}$ & - & - & - & $\begin{array}{l}\text { miR-23b-3p, } \\
\text { miR-29b-3p } \\
\text { and miR-21-5p levels } \\
\text { were independently } \\
\text { associated with IS. } \\
\text { miR-23b-3p, } \\
\text { miR-29b-3p and } \\
\text { miR-181a-5p levels } \\
\text { were associated with } \\
\text { TIA. }\end{array}$ & $\begin{array}{l}\text { Enhanced miR-23b-3p, } \\
\text { miR-29b-3p, miR-181a-5p and } \\
\text { miR-21-5p } \\
\text { levels were closely associated } \\
\text { with IS, and enhanced } \\
\text { miR23b-3p, miR-29b-3p and } \\
\text { miR-181a-5p levels were } \\
\text { associated with TIA. }\end{array}$ & Wu et al., 2017 \\
\hline $\begin{array}{l}\text { Serum specimens from } 86 \text { IS } \\
\text { patients and } 45 \text { controls }\end{array}$ & $\begin{array}{l}0.95 \text { for combination of } \\
\text { miR-1268b, miR-4433b-3p, } \\
\text { and miR-6803-5p }\end{array}$ & $\begin{array}{l}84 \% \text { for } \\
\text { combination of } \\
\text { miR-1268b, } \\
\text { miR-4433b-3p, and } \\
\text { miR-6803-5p }\end{array}$ & $\begin{array}{l}\text { 98\% for combination of } \\
\text { miR-1268b, } \\
\text { miR-4433b-3p, and } \\
\text { miR-6803-5p }\end{array}$ & - & - & - & Sonoda et al., 2019 \\
\hline $\begin{array}{l}\text { Plasma specimens from } 94 \text { AIS } \\
\text { patients with or without } \\
\text { endovascular treatment }\end{array}$ & 0.735 for miR125b-5p & $\begin{array}{l}86.36 \% \text { for } \\
\text { miR125b-5p }\end{array}$ & $\begin{array}{l}55.36 \% \text { for } \\
\text { miR125b-5p }\end{array}$ & - & - & $\begin{array}{l}\text { Higher expression of miR125b-5p } \\
\text { associated with an unfavorable } \\
\text { outcome. }\end{array}$ & $\begin{array}{l}\text { van Kralingen et al., } \\
2019\end{array}$ \\
\hline
\end{tabular}


TABLE 7 | Summary of animal studies which displayed elevation of IncRNAs and miRNAs in stroke.

\begin{tabular}{|c|c|c|c|c|c|c|}
\hline IncRNAs/miRNAs & Animal models & Cells & $\begin{array}{l}\text { Targets/ } \\
\text { Regulators }\end{array}$ & Signaling & Function & References \\
\hline RMST & MCAO mouse model & hippocampal cells & - & - & $\begin{array}{l}\text { RMST induces ischemic brain injury and disrupts } \\
\text { neurological function. }\end{array}$ & Hou and Cheng, 2018 \\
\hline GAS5 & $\begin{array}{l}\text { brain tissues of C57BL/6 J } \\
\text { mice }\end{array}$ & - & miR-137 & $\begin{array}{l}\text { Notch1 signaling } \\
\text { pathway }\end{array}$ & GAS5 is a ceRNA for miR-137 to control Notch1. & Chen et al., 2018a \\
\hline Nespas & $\begin{array}{l}\text { brain tissues of } \mathrm{C} 57 \mathrm{BL} / 6 \mathrm{~J} \\
\text { mice }\end{array}$ & $\begin{array}{l}\text { Mouse BV2 } \\
\text { microglial cells }\end{array}$ & TAK1 & NF-кB signaling & $\begin{array}{l}\text { Nespas induces Neuroinflammation Through } \\
\text { inhibiting NF-kB Activation }\end{array}$ & Deng et al., 2019 \\
\hline MALAT1 & $\begin{array}{l}\text { brain cortex of C57BL/6 J } \\
\text { mice }\end{array}$ & $\begin{array}{l}\text { cortical neurons of } \\
\text { mice }\end{array}$ & Beclin1, miR-30a & - & MALAT1 induces ischemic injury and autophagy. & Guo et al., 2017 \\
\hline H19 & C57BL/6 J mice & - & $\begin{array}{l}\text { miR-675, } \\
\text { IGF1R, pS6 kinase }\end{array}$ & $\begin{array}{l}\text { IGF1 signaling pathway, } \\
\text { mTOR pathway }\end{array}$ & $\begin{array}{l}\text { H19 knockdown mice indicated amelioration on the } \\
\text { performance of a skilled, cortical dependent motor } \\
\text { task. }\end{array}$ & Wang et al., 2020b \\
\hline Maclpil & C57BL/6 mice & - & LCP1 & - & $\begin{array}{l}\text { Maclpil regulates the migration of macrophage and } \\
\text { phagocytosis by LCP1. }\end{array}$ & Wang et al., 2020b \\
\hline MEG3 & C57BL/6 J mice & N2a cell & miR-21 & $\begin{array}{l}\text { miR-21/PDCD4 } \\
\text { pathway }\end{array}$ & $\begin{array}{l}\text { MEG3 promotes ischemic damage and disrupts } \\
\text { overall neurological levels. }\end{array}$ & Zheng et al., 2017 \\
\hline MALAT1 & C57BL/6J mice & $\begin{array}{l}\text { Mouse BMECs and } \\
\text { N2A cells }\end{array}$ & Bim and E-selectin & apoptotic pathways & $\begin{array}{l}\text { Malat1 expression reduced ischemia-induced } \\
\text { endothelial cell death in vitro }\end{array}$ & Zhang et al., 2017b \\
\hline MEG3 & SD rats & - & $\begin{array}{l}\text { BDNF, NGF and } \\
\text { bFGF }\end{array}$ & $\begin{array}{l}\text { Wnt/ } \beta \text {-catenin signaling } \\
\text { pathway }\end{array}$ & $\begin{array}{l}\text { MEG3 reduced nerve growth and enhanced } \\
\text { neurological damage. }\end{array}$ & You and You, 2019 \\
\hline MEG3 & SD rats & $\begin{array}{l}\text { rat brain } \\
\text { microvascular } \\
\text { endothelial cells }\end{array}$ & NOX4 & p53/NOX4 pathway & MEG3 was an important regulator of apoptosis. & Zhan et al., 2017 \\
\hline ANRIL & Wistar rats & neural cells & VEGF & $\begin{array}{l}\text { NF-kB signaling } \\
\text { pathway }\end{array}$ & ANRIL increases VEGF and induces angiogenesis. & Zhang et al., 2017a \\
\hline H19 & Wistar rats & $\begin{array}{l}\text { Neural stem cell } \\
\text { (NSC) }\end{array}$ & $\begin{array}{l}\text { SUZ12, EZH2, } \\
\text { miR-675 }\end{array}$ & $\begin{array}{l}\text { oxidative response, } \\
\text { NF-k } \beta \text { signaling }\end{array}$ & $\begin{array}{l}\text { H19 expression induces the proliferation and } \\
\text { neuronal differentiation of NSCs. }\end{array}$ & Wang et al., 2020b \\
\hline H19 & C57BL/6J mice & - & p53 & p53/Notch1 pathway & H19 represses neurogenesis after IS. & Wang et al., 2019a \\
\hline MALAT1 & C57BL/6 J mice & Primary astrocytes & AQP4, miR-145 & - & $\begin{array}{l}\text { MALAT1 induced cerebral ischemia-reperfusion } \\
\text { damage. }\end{array}$ & Wang et al., 2020a \\
\hline $\begin{array}{l}\text { H19, Lnc-EF094477 } \\
\text { and LncBC090003 }\end{array}$ & Wistar rats & $\begin{array}{l}\text { Neural progenitor } \\
\text { cells (NPCs) }\end{array}$ & - & - & H19 regulated post-stroke neurogenesis. & Liu et al., 2019 \\
\hline GAS5 & C57BL/6 mice & $293 \mathrm{~T}$ & MAP4K4 & - & $\begin{array}{l}\text { GAS5 induses neuron cell apoptosis and nerve } \\
\text { injury in ischemic stroke through inhibiting } \\
\text { DNMT3B-dependent MAP4K4 methylation }\end{array}$ & Deng et al., 2020b \\
\hline
\end{tabular}




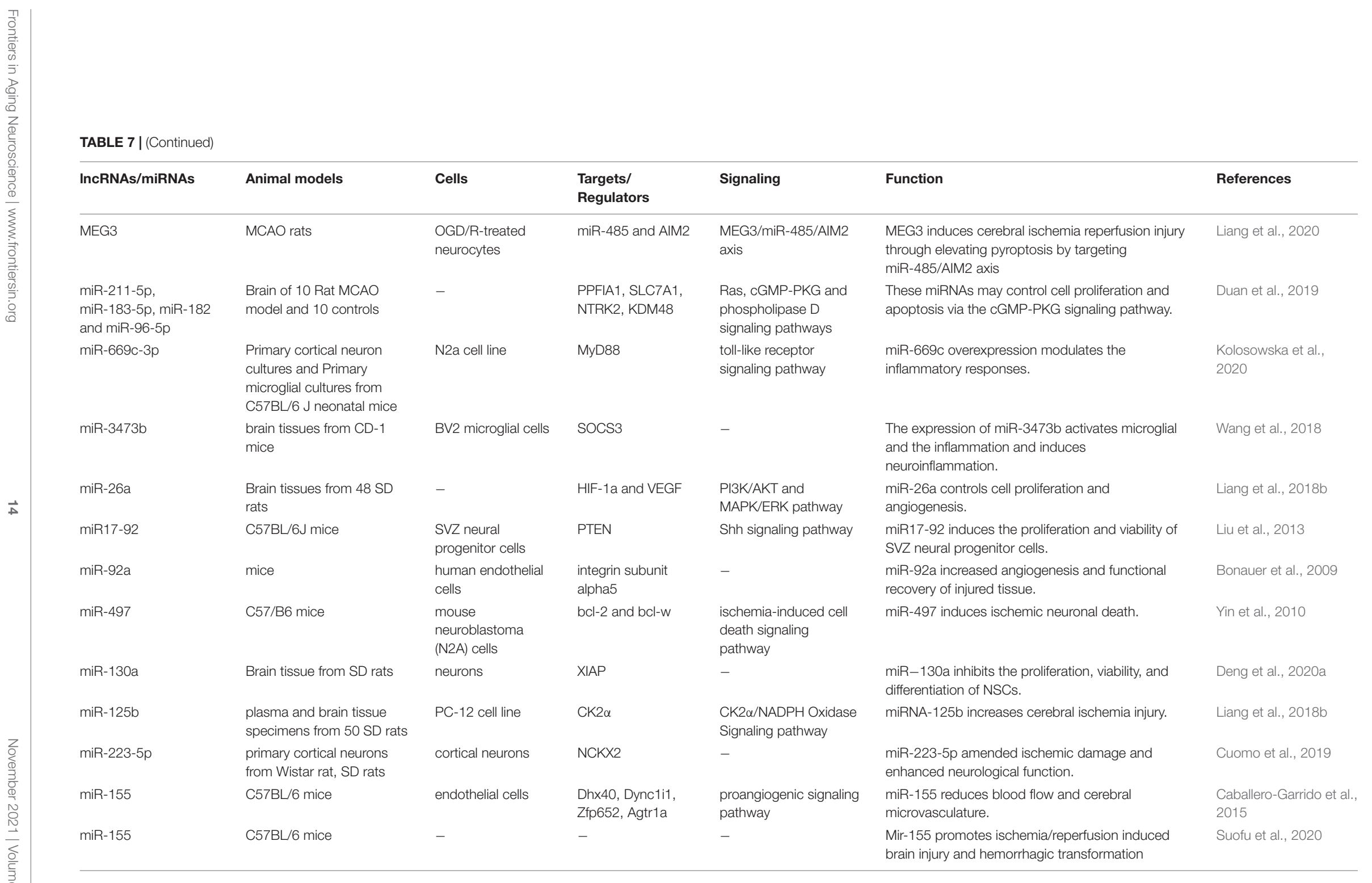


TABLE 8 | Summary of animal studies which displayed down-regulation of IncRNAs and miRNAs in stroke.

\begin{tabular}{|c|c|c|c|c|c|c|}
\hline IncRNAs/miRNAs & Animal models & Cells & $\begin{array}{l}\text { Targets/ } \\
\text { Regulators }\end{array}$ & Signaling pathways & Function & References \\
\hline Meg3 & $\begin{array}{l}268 \text { adult male } \\
\text { Sprague-Dawley rats }\end{array}$ & HMEC-1 & $\begin{array}{l}\text { NICD, Hes-1, and } \\
\text { Hey-1 }\end{array}$ & Notch Pathway & $\begin{array}{l}\text { Meg3 inhibits brain lesions, promotes neurological } \\
\text { outcomes and induces angiogenesis after IS }\end{array}$ & Liu et al., 2017 \\
\hline $\begin{array}{l}\text { LncRNA- } \\
\text { 1810034E14Rik }\end{array}$ & C57BL/6 mice & $\begin{array}{l}\text { primary microglial } \\
\text { cells }\end{array}$ & - & NF-кB pathway & $\begin{array}{l}\text { 1810034E14Rik upregulation decreased the } \\
\text { expression of inflammatory cytokines in IS animal } \\
\text { and inhibited the microglial cells }\end{array}$ & Qu et al., 2019 \\
\hline HOTTIP & C57BL/6 mice & $\begin{array}{l}\text { Primary cortical } \\
\text { neurons }\end{array}$ & miR-143 & $\begin{array}{l}\text { miR-143/hexokinase } 2 \\
\text { pathway }\end{array}$ & $\begin{array}{l}\text { HOTTIP expression reduced ischemic injury and } \\
\text { attenuated glycolytic metabolism in neurons }\end{array}$ & Liang et al., 2018a \\
\hline $\begin{array}{l}\text { Lnc-M64384, } \\
\text { Lnc-MRAK013682, } \\
\text { Lnc-MRAK051099 }\end{array}$ & Wistar rats & $\begin{array}{l}\text { Neural progenitor } \\
\text { cells (NPCs) }\end{array}$ & - & - & $\begin{array}{l}\text { Theses IncRNA may use as an therapy for } \\
\text { amelioration of neurological functions. }\end{array}$ & Liu et al., 2019 \\
\hline IncRNA Rian & C57BL/6 mice & $\begin{array}{l}\text { N2a cell line } \\
\text { (mouse) }\end{array}$ & miR-144-3p & $\begin{array}{l}\text { Rian/miR-144- } \\
\text { 3p/GATA3 } \\
\text { signaling }\end{array}$ & $\begin{array}{l}\text { Rian inhibits cell apoptosis from cerebral } \\
\text { ischemia-reperfusion injury by } \\
\text { Rian/miR-144-3p/GATA3 signaling }\end{array}$ & Yao et al., 2020 \\
\hline $\begin{array}{l}\text { miR-10b-3p and } \\
\text { miR-217-5p }\end{array}$ & $\begin{array}{l}\text { Brain of } 10 \text { Rat MCAO } \\
\text { model and } 10 \text { controls }\end{array}$ & - & $\begin{array}{l}\text { PPFIA1, SLC7A1, } \\
\text { NTRK2, KDM48 }\end{array}$ & $\begin{array}{l}\text { Ras signaling pathway, } \\
\text { cGMP-PKG signaling } \\
\text { pathway, } \\
\text { phospholipase D } \\
\text { signaling pathway }\end{array}$ & $\begin{array}{l}\text { These miRNAs may control cell proliferation and } \\
\text { apoptosis via the cGMP-PKG signaling pathway }\end{array}$ & Duan et al., 2019 \\
\hline miR-424 & $\begin{array}{l}\text { plasma and ipsilateral brain } \\
\text { tissue from C57/BL6 mice }\end{array}$ & BV2 microglial cell & $\begin{array}{l}\text { CDC25A, cyclin } \\
\text { D1, and CDK6 }\end{array}$ & - & $\begin{array}{l}\text { miR-424 suppresses neuronal apoptosis and } \\
\text { microglia activation }\end{array}$ & Zhao et al., 2013 \\
\hline $\begin{array}{l}\text { miR-126-3p and } \\
\text { miR-126-5p }\end{array}$ & ICR mice & - & $\begin{array}{l}\text { SPRED1, VEGFA, } \\
\text { and p-Raf-1 }\end{array}$ & $\begin{array}{l}\text { MAP kinase pathway, } \\
\text { VEGFA/SPRED1/raf-1 } \\
\text { signaling pathway }\end{array}$ & $\begin{array}{l}\text { miR-126-3p reduces the OGD/R-induced } \\
\text { apoptosis and enhances cell survival. }\end{array}$ & Xiao et al., 2020 \\
\hline miRNA-126 & 60 ICR mice & HUVECS & PTPN9 & $\begin{array}{l}\text { AKT and ERK signaling } \\
\text { pathways }\end{array}$ & $\begin{array}{l}\text { miRNA-126 reduces brain atrophy size and } \\
\text { enhances neurobehavioral function. }\end{array}$ & Qu et al., 2019 \\
\hline miR-22 & $16 \mathrm{SD}$ rats & $\begin{array}{l}\text { rat pheochromo- } \\
\text { cytoma cell line }\end{array}$ & $\begin{array}{l}\text { TNF- } \alpha, \text { IL-1 } \beta, \text { IL-6, } \\
\text { IL-18, MIP-2 and } \\
\text { PGE2 }\end{array}$ & p38 MAPK pathway & miRNA-22 inhibits the inflammatory factors in vitro. & Dong et al., 2019 \\
\hline miR-652 & SD rats & SH-SY5Y cell lin & NOX2 & ROS pathway & $\begin{array}{l}\text { miR-652 inhibited NOX2 expression, reduced NOX } \\
\text { activity and ROS level and enhanced apoptosis }\end{array}$ & Zuo et al., 2020 \\
\hline
\end{tabular}


TABLE 8 | (Continued)

\begin{tabular}{|c|c|c|c|c|c|c|}
\hline IncRNAs/miRNAs & Animal models & Cells & $\begin{array}{l}\text { Targets/ } \\
\text { Regulators }\end{array}$ & Signaling pathways & Function & References \\
\hline miR-3552 & $\begin{array}{l}\text { blood and brain specimens } \\
\text { from } 7 \text { brain specimens } \\
\text { from MCAO rats and } 5 \\
\text { brain specimens from } \\
\text { sham-operated rats }\end{array}$ & - & CASP3 & apoptosis pathway & miR-3552 might regulate apoptosis by CASP3 & Li et al., 2020 \\
\hline miR-103 & SD rats & HUVECS & VEGF & - & $\begin{array}{l}\text { miR-103 inhibits the increase of tube length and the } \\
\text { migration of cells and ischemic stroke } \\
\text { angiogenesis, and enhances infarction volume }\end{array}$ & Shi et al., 2018 \\
\hline miR-195 & SD rats & $\begin{array}{l}\text { cerebral cortex } \\
\text { cells RCCNC }\end{array}$ & KLF5 & JNK signaling pathway & $\begin{array}{l}\text { miR-195 upregulation suppresses cerebral } \\
\text { infarction, loss of neuronal cells, and induces } \\
\text { synaptic plasticity }\end{array}$ & Chang et al., 2020 \\
\hline miR-122 & $\begin{array}{l}\text { Blood specimens from SD } \\
\text { rats }\end{array}$ & - & $\begin{array}{l}\text { Vcam1, Nos2, } \\
\text { Pla2g2a }\end{array}$ & $\begin{array}{l}\text { granulocyte/ } \\
\text { agranulocyte adhesion } \\
\text { and diapedesis, } \\
\text { leukocyte } \\
\text { extravasation, } \\
\text { eicosanoid signaling } \\
\text { and atherosclerosis } \\
\text { signaling }\end{array}$ & miR-122 upregulation enhances stroke outcomes. & Liu da et al., 2016 \\
\hline miR-579-3p & brain tissue from SD rats & neurons & NRIP1 & NF-êB pathway & $\begin{array}{l}\text { miR-579-3p has neuroprotective effect and reduces } \\
\text { inflammation and apoptosis. }\end{array}$ & Jia et al., 2020 \\
\hline $\operatorname{miR}-7 a-5 p$ & $\begin{array}{l}\text { spontaneously hypertensive } \\
\text { rats, C57BL/6 mice }\end{array}$ & PC12 cells & $\alpha-\operatorname{Syn}$ & - & miR-7a-5p improved ischemic brain damage. & Kim et al., 2018 \\
\hline miR-219 & $\begin{array}{l}\text { Serum and brain tissue } \\
\text { from Wistar rats }\end{array}$ & - & NMDA & - & miR-219 modulated ischemia by NMDA. & Silva et al., 2017 \\
\hline miR-99a & C57BL/6 mice & neuro-2a cells & $\begin{array}{l}\text { cyclin D1 and } \\
\text { CDK6 }\end{array}$ & - & $\begin{array}{l}\text { miR-99a decreased neuronal injury after cerebral } \\
\text { l/R. }\end{array}$ & Tao et al., 2015 \\
\hline miR-126 & SD rats & $\begin{array}{l}\text { adipose derived } \\
\text { stem cells (ADSCs) }\end{array}$ & - & - & $\begin{array}{l}\text { miR-126 induced neurogenesis and } \\
\text { vasculogenesis, and suppresses microglial } \\
\text { activation and inflammatory response after ischemic } \\
\text { stroke. }\end{array}$ & Geng et al., 2019 \\
\hline miR-130a-3p & MCAO/R mice & $\begin{array}{l}\text { SH-SY5Y and N2a } \\
\text { cells }\end{array}$ & DAPK1 & $\begin{array}{l}\text { H19/miR-130a- } \\
\text { 3p/DAPK1 } \\
\text { axis }\end{array}$ & $\begin{array}{l}\text { miR-130a-3p controls apoptosis in SH-SY5Y and } \\
\text { N2a cells as well as on cerebral damage by I/R. }\end{array}$ & Feng et al., 2021 \\
\hline
\end{tabular}


regions after regional cerebral ischemia has shown up-regulation of 20 miRNAs while down-regulation of 17 miRNAs in the infarct area among them have been miR-211-5p, miR-183-5p, miR-182, and miR-96-5p which have been functionally related with some important pathways in the neurons (Duan et al., 2019). Table 7 summarizes the data regarding the roles of upregulated non-coding RNAs in the pathogenesis of IS as revealed by animal studies.

Meg3 is a down-regulated lncRNA after IS. Up-regulation of Meg3 has inhibited functional recovery and diminished capillary mass after IS. On the other hand, its silencing has amended brain lesions and enhanced angiogenesis after IS. Meg3 exerts these functions through inhibiting notch pathway (Liu et al., 2017). Expression of IncRNA-1810034E14Rik has also been down-regulated in LPS-exposed or oxygen-glucose deprivationinduced microglial cells. Up-regulation of 1810034E14Rik has reduced the infarct volume, ameliorated brain injury in MCAO model and decreased production of inflammatory cytokines both in the animal model and in microglial cells. Besides, 1810034E14Rik up-regulation could block the induction of microglial cells and suppress p65 phosphorylation of p65 (Qu et al., 2019). The above-mentioned examples indicate that down-regulation of lncRNAs in IS might be a compensative mechanism for amelioration of neuron damage or can be directly participate in the pathogenic mechanisms during IS. Table 8 summarizes the data regarding the roles of downregulated non-coding RNAs in the pathogenesis of IS as revealed by animal studies.

\section{DISCUSSION}

A wealth of information about the role of non-coding RNAs in the development of IS has been obtained from combination of RNA-sequencing assays and bioinformatics assays such as GO, KEGG pathway enrichment assays and network analyses. These kinds of studies not only exhibited dysregulation of these transcripts, but also provided mechanistical insights about their route of actions. Generally, non-coding RNAs might participate in the pathophysiology of IS through different routes. As a number of differentially expressed IncRNAs between IS patients and healthy controls map to genomic loci near IS-associated genes, regulation of gene expression through cis-acting modes is a possible route. Another possible mechanism of contribution of lncRNAs in the pathology of IS is their ceRNA role. MEG3/miR424-5p, KCNQ1OT1/miR-200a and MALAT1/miR-205-5p are few examples of interplay between lncRNAs and miRNAs in the context of IS.

\section{REFERENCES}

Bam, M., Yang, X., Sen, S., Zumbrun, E. E., Dennis, L., Zhang, J., et al. (2018). Characterization of dysregulated miRNA in Peripheral blood mononuclear cells from ischemic stroke patients. Mol. Neurobiol. 55, 1419-1429. doi: 10.1007/s12035-0160347-8
Aberrant expression of non-coding RNAs in IS patients might be due to the presence of a number of genomic variants within the coding genes as demonstrated for ANRIL lncRNA. This lncRNA is among the mostly assessed lncRNAs in IS. However, the results of all studies are not consistent in this regard. Such inconsistency might be due to phase of sampling during the course of IS or the presence of other confounding parameters. The presence of IncRNAs in the serum specimens and exosomes extracted from these specimens facilitates diagnosis of IS and its clinical variants using this noninvasive route of sampling.

MicroRNAs contribute in the pathogenesis of IS through modulation of genes implicated in the atherosclerosis or inflammatory responses. Exosomal miRNAs might affect communication between several types of cells including endothelial and smooth muscle cells. IS-related circulating miRNAs might hypothetically exert similar functions. Yet, this hypothesis should be judged in upcoming studies. Peripheral expression of miRNAs can be used to differentiate IS patients from healthy subjects or IS patients from other related conditions such as HS. Moreover, their signature might predict recovery from IS-related clinical signs.

The observed sex-biased pattern of differentially expression of IncRNAs (Dykstra-Aiello et al., 2016) might determine different pathogenic processes for the evolution of IS among men and women which should be further examined. Moreover, a number of investigations have displayed specific lncRNA signatures at certain time points following IS, demonstrating the specific roles of lncRNAs in each step of pathogenic processes following IS.

In spite of conduction of various functional studies to unravel the role of non-coding RNAs in IS, therapeutic application of these transcripts have not been clarified. Therefore, future investigation should appraise the possibility of using these transcripts as therapeutic targets in IS. Another limitation of most of mentioned studies is their relatively small sample sizes and lack of simultaneous appraisal of exposures and outcomes in cross-sectional studies. Application of non-coding RNAs as therapeutic targets for IS has faced some challenges in terms of safe delivery of the drug to specific targets, avoidance of off-target effects and determination of best time for intervention. This filed is still in its infancy.

\section{AUTHOR CONTRIBUTIONS}

SG-F wrote the manuscript and revised it. MT designed the study and supervised it. NA, ZS-F, and BH collected the data and designed the figures and the tables. All authors approved the manuscript.

Bonauer, A., Carmona, G., Iwasaki, M., Mione, M., Koyanagi, M., Fischer, A., et al. (2009). MicroRNA-92a controls angiogenesis and functional recovery of ischemic tissues in mice. Science 324, 1710-1713. doi: 10.1126/science.1174381 Caballero-Garrido, E., Pena-Philippides, J. C., Lordkipanidze, T., Bragin, D., Yang, Y., Erhardt, E. B., et al. (2015). In vivo inhibition of miR-155 promotes recovery after experimental mouse stroke. J. Neurosci. 35, 12446-12464. doi: 10.1523/ jneurosci.1641-15.2015 
Chang, L., Zhang, W., Shi, S., Peng, Y., Wang, D., Zhang, L., et al. (2020). microRNA-195 attenuates neuronal apoptosis in rats with ischemic stroke through inhibiting KLF5-mediated activation of the JNK signaling pathway. Mol. Med. 26:31. doi: 10.1186/s10020-020-00150-w

Chen, F., Zhang, L., Wang, E., Zhang, C., and Li, X. (2018a). LncRNA GAS5 regulates ischemic stroke as a competing endogenous RNA for miR-137 to regulate the Notch1 signaling pathway. Biochem. Biophys. Res. Commun. 496, 184-190. doi: 10.1016/j.bbrc.2018.01.022

Chen, Y., Song, Y., Huang, J., Qu, M., Zhang, Y., Geng, J., et al. (2017). Increased circulating exosomal miRNA-223 is associated with acute ischemic stroke. Front. Neurol. 8:57. doi: 10.3389/fneur.2017.00057

Chen, Z., Wang, K., Huang, J., Zheng, G., Lv, Y., Luo, N., et al. (2018b). Upregulated serum MiR-146b serves as a biomarker for acute ischemic stroke. Cell. Physiol. Biochem. 45, 397-405. doi: 10.1159/000486916

Cheng, J., Kapranov, P., Drenkow, J., Dike, S., Brubaker, S., Patel, S., et al. (2005). Transcriptional maps of 10 human chromosomes at 5-nucleotide resolution. Science 308, 1149-1154. doi: 10.1126/science. 1108625

Cuomo, O., Cepparulo, P., Anzilotti, S., Serani, A., Sirabella, R., Brancaccio, P., et al. (2019). Anti-miR-223-5p ameliorates ischemic damage and improves neurological function by preventing NCKX2 downregulation after ischemia in rats. Mol. Therapy Nucleic Acids 18, 1063-1071. doi: 10.1016/j.omtn.2019.10. 022

Deng, Q.-W., Li, S., Wang, H., Sun, H.-L., Zuo, L., Gu, Z.-T., et al. (2018). Differential long noncoding RNA expressions in peripheral blood mononuclear cells for detection of acute ischemic stroke. Clin. Sci. 132, 1597-1614. doi: $10.1042 / \operatorname{cs} 20180411$

Deng, W., Fan, C., Zhao, Y., Mao, Y., Li, J., Zhang, Y., et al. (2020a)). MicroRNA130 a regulates neurological deficit and angiogenesis in rats with ischaemic stroke by targeting XIAP. J. Cell Mol. Med. 24, 10987-11000. doi: 10.1111/ jcmm.15732

Deng, Y., Chen, D., Gao, F., Lv, H., Zhang, G., Sun, X., et al. (2020b). Silencing of long non-coding RNA GAS5 suppresses neuron cell apoptosis and nerve injury in ischemic stroke through inhibiting DNMT3B-Dependent MAP4K4 methylation. Trans. Stroke Res. 11, 950-966. doi: 10.1007/s12975-019-00 770-3

Deng, Y., Chen, D., Wang, L., Gao, F., Jin, B., Lv, H., et al. (2019). Silencing of long noncoding RNA nespas aggravates microglial cell death and neuroinflammation in ischemic stroke. Stroke 50, 1850-1858. doi: 10.1161/ STROKEAHA.118.023376

Derrien, T., Johnson, R., Bussotti, G., Tanzer, A., Djebali, S., Tilgner, H., et al. (2012). The GENCODE v7 catalog of human long noncoding RNAs: analysis of their gene structure, evolution, and expression. Genome Res. 22, 1775-1789. doi: $10.1101 /$ gr.132159.111

Dong, H., Cui, B., and Hao, X. (2019). MicroRNA-22 alleviates inflammation in ischemic stroke via p38 MAPK pathways. Mol. Med. Rep. 20, 735-744. doi: 10.3892/mmr.2019.10269

Duan, X., Gan, J., Peng, D. Y., Bao, Q., Xiao, L., Wei, L., et al. (2019). Identification and functional analysis of microRNAs in rats following focal cerebral ischemia injury. Mol. Med. Rep. 19, 4175-4184. doi: 10.3892/mmr.2019.10073

Dykstra-Aiello, C., Jickling, G. C., Ander, B. P., Shroff, N., Zhan, X., Liu, D., et al. (2016). Altered expression of long noncoding RNAs in blood after ischemic stroke and proximity to putative stroke risk loci. Stroke 47, 2896-2903. doi: 10.1161/STROKEAHA.116.013869

Edwardson, M. A., Zhong, X., Cheema, A., and Dromerick, A. (2018a). Plasma microRNA markers of upper limb recovery following human stroke. J. Clin. Trans. Sci. 2:45. doi: 10.1017/cts.2018.176

Edwardson, M. A., Zhong, X., Fiandaca, M. S., Federoff, H. J., Cheema, A. K., and Dromerick, A. W. (2018b). Plasma microRNA markers of upper limb recovery following human stroke. Sci. Rep. 8:12558.

Fang, Y., and Fullwood, M. J. (2016). Roles, functions, and mechanisms of long non-coding RNAs in cancer. Genom. Proteom. Bioinform. 14, 42-54. doi: 10.1016/j.gpb.2015.09.006

Feigin, V. L., Krishnamurthi, R. V., Parmar, P., Norrving, B., Mensah, G. A., Bennett, D. A., et al. (2015). Update on the global burden of ischemic and hemorrhagic stroke in 1990-2013: the GBD 2013 study. Neuroepidemiology 45, 161-176. doi: 10.1159/000441085

Feng, L., Guo, J., and Ai, F. (2019). Circulating long noncoding RNA ANRIL downregulation correlates with increased risk, higher disease severity and elevated pro-inflammatory cytokines in patients with acute ischemic stroke. J. Clin. Lab. Anal. 33:e22629. doi: 10.1002/jcla.22629

Feng, M., Zhu, X., and Zhuo, C. (2021). H19/miR-130a-3p/DAPK1 axis regulates the pathophysiology of neonatal hypoxic-ischemia encephalopathy. Neurosci. Res. 163, 52-62. doi: 10.1016/j.neures.2020.03.005

Gan, C., Wang, C., and Tan, K. (2012). Circulatory microRNA-145 expression is increased in cerebral ischemia. Genet. Mol. Res. 11, 147-152. doi: 10.4238/2012. January.27.1

Gao, C., Zhang, C.-C., Yang, H.-X., and Hao, Y.-N. (2020). MALAT1 protected the angiogenesis function of human brain microvascular endothelial cells (HBMECs) under oxygen glucose deprivation/re-oxygenation (OGD/R) challenge by interacting with miR-205-5p/VEGFA pathway. Neuroscience 435 , 135-145. doi: 10.1016/j.neuroscience.2020.03.027

Geng, W., Tang, H., Luo, S., Lv, Y., Liang, D., Kang, X., et al. (2019). Exosomes from miRNA-126-modified ADSCs promotes functional recovery after stroke in rats by improving neurogenesis and suppressing microglia activation. Am. J. Transl. Res. 11, 780-792.

Guang, Y., Zhendong, L., Lu, W., Xin, C., Xiaoxiong, W., Qi, D., et al. (2019). MicroRNA-195 protection against focal cerebral ischemia by targeting CX3CR1. J. Neurosurg. JNS 131, 1445-1454. doi: 10.3171/2018.5.JNS173061

Guo, D., Ma, J., Yan, L., Li, T., Li, Z., Han, X., et al. (2017). Down-Regulation of Incrna MALAT1 attenuates neuronal cell death through suppressing beclin1dependent autophagy by regulating Mir-30a in cerebral ischemic stroke. Cell. Physiol. Biochem. 43, 182-194. doi: 10.1159/000480337

Guo, X., Yang, J., Liang, B., Shen, T., Yan, Y., Huang, S., et al. (2018). Identification of novel LncRNA biomarkers and construction of LncRNA-Related networks in han chinese patients with ischemic stroke. Cell. Physiol. Biochem. 50, 21572175. doi: $10.1159 / 000495058$

Hou, X.-X., and Cheng, H. (2018). Long non-coding RNA RMST silencing protects against middle cerebral artery occlusion (MCAO)-induced ischemic stroke. Biochem. Biophys. Res. Commun. 495, 2602-2608. doi: 10.1016/j.bbrc.2017.12. 087

Huang, S., Lv, Z., Guo, Y., Li, L., Zhang, Y., Zhou, L., et al. (2016). Identification of blood Let-7e-5p as a biomarker for ischemic stroke. PLoS One 11:e0163951. doi: 10.1371/journal.pone.0163951

Huang, Y., Wang, L., Mao, Y., and Nan, G. (2019). Long noncoding RNA-H19 contributes to atherosclerosis and induces ischemic stroke via the upregulation of acid phosphatase 5. Front. Neurol. 10:32. doi: 10.3389/fneur.2019.00032

Ji, Q., Ji, Y., Peng, J., Zhou, X., Chen, X., Zhao, H., et al. (2016). Increased brainspecific MiR-9 and MiR-124 in the serum exosomes of acute ischemic stroke patients. PLoS One 11:e0163645. doi: 10.1371/journal.pone.0163645

Jia, J., Cui, Y., Tan, Z., Ma, W., and Jiang, Y. (2020). MicroRNA-579-3p exerts neuroprotective effects against ischemic stroke via anti-inflammation and antiapoptosis. Neuropsychiatric Dis. Treatment 16, 1229-1238. doi: 10.2147/ndt. s240698

Jia, L., Hao, F., Wang, W., and Qu, Y. (2015). Circulating miR-145 is associated with plasma high-sensitivity C-reactive protein in acute ischemic stroke patients. Cell Biochem. Funct. 33, 314-319. doi: 10.1002/cbf.3116

Jickling, G. C., Ander, B. P., Zhan, X., Noblett, D., Stamova, B., and Liu, D. (2014). microRNA expression in peripheral blood cells following acute ischemic stroke and their predicted gene targets. PLoS One 9:e99283. doi: 10.1371/journal.pone. 0099283

Jin, F., and Xing, J. (2017). Circulating pro-angiogenic and anti-angiogenic microRNA expressions in patients with acute ischemic stroke and their association with disease severity. Neurol. Sci. 38, 2015-2023. doi: 10.1007/ s10072-017-3071-x

Jo, M. H., Shin, S., Jung, S.-R., Kim, E., Song, J.-J., and Hohng, S. (2015). Human Argonaute 2 has diverse reaction pathways on target RNAs. Mol. Cell 59, 117-124. doi: 10.1016/j.molcel.2015.04.027

Kim, T., Mehta, S. L., Morris-Blanco, K. C., Chokkalla, A. K., Chelluboina, B., Lopez, M., et al. (2018). The microRNA miR-7a-5p ameliorates ischemic brain damage by repressing $\alpha$-synuclein. Sci. Signal. 11:eaat4285. doi: 10.1126/ scisignal.aat 4285

Kolosowska, N., Gotkiewicz, M., Dhungana, H., Giudice, L., Giugno, R., Box, D., et al. (2020). Intracerebral overexpression of miR-669c is protective in mouse ischemic stroke model by targeting MyD88 and inducing alternative microglial/macrophage activation. J. Neuroinflamm. 17:194. doi: 10.1186/ s12974-020-01870-w 
Kotb, H. G., Ibrahim, A. H., Mohamed, E. F., Ali, O. M., Hassanein, N., Badawy, D., et al. (2019). The expression of microRNA 146a in patients with ischemic stroke: an observational study. Int. J. Gen. Med. 12, 273-278. doi: 10.2147/ IJGM.S213535

Lee, R. C., Feinbaum, R. L., and Ambros, V. (1993). The C. elegans heterochronic gene lin-4 encodes small RNAs with antisense complementarity to lin-14. Cell 75, 843-854. doi: 10.1016/0092-8674(93)9 0529-y

Leung, L. Y., Chan, C. P., Leung, Y. K., Jiang, H. L., Abrigo, J. M., Wang de, F., et al. (2014). Comparison of miR-124-3p and miR-16 for early diagnosis of hemorrhagic and ischemic stroke. Clin. Chim. Acta 433, 139-144. doi: 10.1016/j.cca.2014.03.007

Li, L., Dong, L., Zhao, J., He, W., Chu, B., Zhang, J., et al. (2020). Circulating miRNA-3552 as a potential biomarker for ischemic stroke in rats. BioMed. Res. Int. 2020:4501393. doi: 10.1155/2020/4501393

Li, P., Teng, F., Gao, F., Zhang, M., Wu, J., and Zhang, C. (2015). Identification of circulating MicroRNAs as potential biomarkers for detecting acute ischemic stroke. Cell Mol. Neurobiol. 35, 433-447.

Liang, J., Wang, Q., Li, J.-Q., Guo, T., and Yu, D. (2020). Long non-coding RNA MEG3 promotes cerebral ischemia-reperfusion injury through increasing pyroptosis by targeting miR-485/AIM2 axis. Exp. Neurol. 325:113139. doi: 10.1016/j.expneurol.2019.113139

Liang, Y., Xu, J., Wang, Y., Tang, J. Y., Yang, S. L., Xiang, H. G., et al. (2018a). Inhibition of MiRNA-125b decreases cerebral ischemia/reperfusion injury by targeting CK2 $\alpha / \mathrm{NADPH}$ oxidase signaling. Cell. Physiol. Biochem. 45, 18181826. doi: $10.1159 / 000487873$

Liang, Z., Chi, Y. J., Lin, G. Q., Luo, S. H., Jiang, Q. Y., and Chen, Y. K. (2018b). MiRNA-26a promotes angiogenesis in a rat model of cerebral infarction via PI3K/AKT and MAPK/ERK pathway. Eur. Rev. Med. Pharmacol. Sci. 22, 3485-3492. doi: 10.26355/eurrev_201806_15175

Liaw, N., and Liebeskind, D. (2020). Emerging therapies in acute ischemic stroke. F1000Res 9:F1000 Faculty Rev-546.

Liu, J., Li, Q., Zhang, K.-S., Hu, B., Niu, X., Zhou, S.-M., et al. (2017). Downregulation of the long non-coding RNA Meg3 promotes angiogenesis after ischemic brain injury by activating notch signaling. Mol. Neurobiol. 54, 8179-8190. doi: 10.1007/s12035-016-0270-z

Liu, X. S., Chopp, M., Wang, X. L., Zhang, L., Hozeska-Solgot, A., Tang, T., et al. (2013). MicroRNA-17-92 cluster mediates the proliferation and survival of neural progenitor cells after stroke. J. Biol. Chem. 288, 12478-12488. doi: 10.1074/jbc.M112.449025

Liu, X. S., Fan, B., Wang, X., Chopp, M., and Zhang, Z. G. (2019). "Differential long noncoding RNA and messenger RNA expression profiling and functional network analysis in stroke-induced neurogenesis," in Proceedings of the 2019 IEEE International Conference on Bioinformatics and Biomedicine (BIBM), (Piscataway, NJ: IEEE).

Liu, Y., Zhang, J., Han, R., Liu, H., Sun, D., and Liu, X. (2015). Downregulation of serum brain specific microRNA is associated with inflammation and infarct volume in acute ischemic stroke. J. Clin. Neurosci. 22, 291-295. doi: 10.1016/j. jocn.2014.05.042

Liu da, Z., Jickling, G. C., Ander, B. P., Hull, H., Zhan, X., Cox, C., et al. (2016). Elevating microRNA-122 in blood improves outcomes after temporary middle cerebral artery occlusion in rats. J. Cereb. Blood Flow Metab. 36, 1374-1383. doi: $10.1177 / 0271678 X 15610786$

Long, G., Wang, F., Li, H., Yin, Z., Sandip, C., Lou, Y., et al. (2013). Circulating miR-30a, miR-126 and let-7b as biomarker for ischemic stroke in humans. BMC Neurol. 13:178. doi: 10.1186/1471-2377-13-178

O’Brien, J., Hayder, H., Zayed, Y., and Peng, C. (2018). Overview of microRNA biogenesis, mechanisms of actions, and circulation. Front. Endocrin. 9:402. doi: $10.3389 /$ fendo.2018.00402

Peng, G., Yuan, Y., Wu, S., He, F., Hu, Y., and Luo, B. (2015). MicroRNA let-7e is a potential circulating biomarker of acute stage ischemic stroke. Trans. Stroke Res. 6, 437-445. doi: 10.1007/s12975-015-0422-x

Qu, M., Pan, J., Wang, L., Zhou, P., Song, Y., Wang, S., et al. (2019). MicroRNA126 regulates angiogenesis and neurogenesis in a mouse model of focal cerebral ischemia. Mol. Therapy Nucleic Acids 16, 15-25. doi: 10.1016/j.omtn.2019.02. 002

Salinas, J., Lin, H., Aparico, H. J., Huan, T., Liu, C., Rong, J., et al. (2019). Whole blood microRNA expression associated with stroke: results from the framingham heart study. PLoS One 14:e0219261. doi: 10.1371/journal.pone. 0219261

Sepramaniam, S., Tan, J.-R., Tan, K.-S., DeSilva, D. A., Tavintharan, S., Woon, F.-P., et al. (2014). Circulating microRNAs as biomarkers of acute stroke. Int. J. Mol. Sci. 15, 1418-1432.

Shi, F.-P., Wang, X.-H., Zhang, H.-X., Shang, M.-M., Liu, X.-X., Sun, H.-M., et al. (2018). MiR-103 regulates the angiogenesis of ischemic stroke rats by targeting vascular endothelial growth factor (VEGF). Iran. J. Basic Med. Sci. 21, 318-324. doi: 10.22038/IJBMS.2018.27267.6657

Silva, C. I., Novais, P. C., Rodrigues, A. R., Carvalho, C. A. M., Colli, B. O., Carlotti, C. G. Jr., et al. (2017). Expression of NMDA receptor and microRNA-219 in rats submitted to cerebral ischemia associated with alcoholism. Arquivos de Neuro-Psiquiatria 75, 30-35. doi: 10.1590/0004-282X20160188

Sonoda, T., Matsuzaki, J., Yamamoto, Y., Sakurai, T., Aoki, Y., Takizawa, S., et al. (2019). Serum MicroRNA-Based risk prediction for stroke. Stroke 50, 1510-1518. doi: 10.1161/STROKEAHA.118.023648

Sørensen, S. S., Nygaard, A.-B., Carlsen, A. L., Heegaard, N. H. H., Bak, M., and Christensen, T. (2017). Elevation of brain-enriched miRNAs in cerebrospinal fluid of patients with acute ischemic stroke. Biomarker Res. 5:24. doi: 10.1186/ s40364-017-0104-9

Spinetti, G., Fortunato, O., Caporali, A., Shantikumar, S., Marchetti, M., Meloni, M., et al. (2013). MicroRNA-15a and microRNA-16 impair human circulating proangiogenic cell functions and are increased in the proangiogenic cells and serum of patients with critical limb ischemia. Circ. Res. 112, 335-346. doi: 10.1161/CIRCRESAHA.111.300418

Suofu, Y., Wang, X., He, Y., Li, F., Zhang, Y., Carlisle, D. L., et al. (2020). Mir155 knockout protects against ischemia/reperfusion-induced brain injury and hemorrhagic transformation. NeuroReport 31, 235-239. doi: 10.1097/WNR. 0000000000001382

Tao, Z., Zhao, H., Wang, R., Liu, P., Yan, F., Zhang, C., et al. (2015). Neuroprotective effect of microRNA-99a against focal cerebral ischemiareperfusion injury in mice. J. Neurol. Sci. 355, 113-119. doi: 10.1016/j.jns.2015. 05.036

Tian, C., Li, Z., Yang, Z., Huang, Q., Liu, J., and Hong, B. (2016). Plasma MicroRNA-16 is a biomarker for diagnosis, stratification, and prognosis of hyperacute cerebral infarction. PLoS One 11:e0166688. doi: 10.1371/journal. pone. 0166688

Tiedt, S., Prestel, M., Malik, R., Schieferdecker, N., Duering, M., Kautzky, V., et al. (2017). RNA-Seq identifies circulating miR-125a-5p, miR-125b-5p, and miR-143-3p as potential biomarkers for acute ischemic stroke. Circ. Res. 121, 970-980. doi: 10.1161/CIRCRESAHA.117.311572

van Kralingen, J. C., McFall, A., Ord, E. N. J., Coyle, T. F., Bissett, M., McClure, J. D., et al. (2019). Altered extracellular vesicle microRNA expression in ischemic stroke and small vessel disease. Trans. Stroke Res. 10, 495-508. doi: 10.1007/ s12975-018-0682-3

Vijayan, M., Kumar, S., Yin, X., Zafer, D., Chanana, V., Cengiz, P., et al. (2018). Identification of novel circulatory microRNA signatures linked to patients with ischemic stroke. Hum. Mol. Genet. 27, 2318-2329. doi: 10.1093/hmg/ ddy 136

Wang, H., Zheng, X., Jin, J., Zheng, L., Guan, T., Huo, Y., et al. (2020a). LncRNA MALAT1 silencing protects against cerebral ischemia-reperfusion injury through miR-145 to regulate AQP4. J. Biomed. Sci. 27:40. doi: 10.1186/ s12929-020-00635-0

Wang, J., Cao, B., Zhao, H., Gao, Y., Luo, Y., Chen, Y., et al. (2019a). Long noncoding RNA H19 prevents neurogenesis in ischemic stroke through p53/Notch1 pathway. Brain Res. Bull. 150, 111-117. doi: 10.1016/j.brainresbull. 2019.05.009

Wang, J., Ruan, J., Zhu, M., Yang, J., Du, S., Xu, P., et al. (2019b). Predictive value of long noncoding RNA ZFAS1 in patients with ischemic stroke. Clin. Exp. Hypertens 41, 615-621. doi: 10.1080/10641963.2018.1529774

Wang, J., Zhao, H., Fan, Z., Li, G., Ma, Q., Tao, Z., et al. (2017). Long noncoding RNA H19 promotes neuroinflammation in ischemic stroke by driving histone deacetylase 1-Dependent M1 microglial polarization. Stroke 48, 2211-2221. doi: 10.1161/STROKEAHA.117.017387

Wang, W., Sun, G., Zhang, L., Shi, L., and Zeng, Y. (2014). Circulating microRNAs as novel potential biomarkers for early diagnosis of acute stroke in humans. J. Stroke Cereb. Dis. 23, 2607-2613. doi: 10.1016/j.jstrokecerebrovasdis.2014. 06.002 
Wang, X., Chen, S., Ni, J., Cheng, J., Jia, J., and Zhen, X. (2018). miRNA-3473b contributes to neuroinflammation following cerebral ischemia. Cell Death Dis. 9:11. doi: 10.1038/s41419-017-0014-7

Wang, Y., Luo, Y., Yao, Y., Ji, Y., Feng, L., Du, F., et al. (2020b). Silencing the IncRNA Maclpil in pro-inflammatory macrophages attenuates acute experimental ischemic stroke via LCP1 in mice. J. Cereb. Blood Flow Metab. 40, 747-759. doi: 10.1177/0271678X19836118

Wu, J., Du, K., and Lu, X. (2015). Elevated expressions of serum miR-15a, miR-16, and miR-17-5p are associated with acute ischemic stroke. Int. J. Clin. Exp. Med. 8, 21071-21079.

Wu, J., Fan, C. L., Ma, L. J., Liu, T., Wang, C., Song, J. X., et al. (2017). Distinctive expression signatures of serum microRNAs in ischaemic stroke and transient ischaemic attack patients. Thrombosis Haemostasis 117, 992-1001. doi: 10. 1160/TH16-08-0606

Xiang, Y., Zhang, Y., Xia, Y., Zhao, H., Liu, A., and Chen, Y. (2020). LncRNA MEG3 targeting miR-424-5p via MAPK signaling pathway mediates neuronal apoptosis in ischemic stroke. Aging 12, 3156-3174. doi: 10.18632/aging.10 2790

Xiao, Z. H., Wang, L., Gan, P., He, J., Yan, B. C., and Ding, L. D. (2020). Dynamic changes in miR-126 expression in the hippocampus and penumbra following experimental transient global and focal cerebral ischemiareperfusion. Neurochem. Res. 45, 1107-1119. doi: 10.1007/s11064-020-02 986-4

$\mathrm{Xu}, \mathrm{X}$., Zhuang, C., and Chen, L. (2020). Exosomal long non-coding RNA expression from serum of patients with acute minor stroke. Neuropsychiatric Dis. Treatment 16:153. doi: 10.2147/NDT.S230332

Yang, J., Gu, L., Guo, X., Huang, J., Chen, Z., Huang, G., et al. (2018). LncRNA ANRIL expression and ANRIL gene polymorphisms contribute to the risk of ischemic stroke in the chinese han population. Cell Mol. Neurobiol. 38, 1253-1269. doi: 10.1007/s10571-018-0593-6

Yao, P., Li, Y.-L., Chen, Y., Shen, W., Wu, K.-Y., and Xu, W.-H. (2020). Overexpression of long non-coding RNA Rian attenuates cell apoptosis from cerebral ischemia-reperfusion injury via Rian/miR-144-3p/GATA3 signaling. Gene 737:144411. doi: 10.1016/j.gene.2020.144411

Yin, K.-J., Deng, Z., Huang, H., Hamblin, M., Xie, C., Zhang, J., et al. (2010). miR-497 regulates neuronal death in mouse brain after transient focal cerebral ischemia. Neurobiol. Dis. 38, 17-26. doi: 10.1016/j.nbd.2009. 12.021

You, D., and You, H. (2019). Repression of long non-coding RNA MEG3 restores nerve growth and alleviates neurological impairment after cerebral ischemiareperfusion injury in a rat model. Biomed. Pharmacotherapy 111, 1447-1457. doi: 10.1016/j.biopha.2018.12.067

Zeng, W., and Jin, J. (2020). The correlation of serum long non-coding RNA ANRIL with risk factors, functional outcome, and prognosis in atrial fibrillation patients with ischemic stroke. J. Clin. Lab. Anal. 34:e23352. doi: 10.1002/jcla. 23352

Zhan, R., Xu, K., Pan, J., Xu, Q., Xu, S., and Shen, J. (2017). Long noncoding RNA MEG3 mediated angiogenesis after cerebral infarction through regulating p53/NOX4 axis. Biochem. Biophys. Res. Commun. 490, 700-706. doi: 10.1016/j. bbrc.2017.06.104

Zhang, B., Wang, D., Ji, T.-F., Shi, L., and Yu, J.-L. (2017a). Overexpression of lncRNA ANRIL up-regulates VEGF expression and promotes angiogenesis of diabetes mellitus combined with cerebral infarction by activating NF- $\kappa$ B signaling pathway in a rat model. Oncotarget 8, 17347-17359. doi: 10.18632/ oncotarget.14468

Zhang, X., Tang, X., Liu, K., Hamblin, M. H., and Yin, K.-J. (2017b). Long noncoding RNA Malat1 regulates cerebrovascular pathologies in ischemic stroke. J. Neurosci. 37, 1797-1806. doi: 10.1523/jneurosci.3389-16.2017

Zhanin, I. S., Gusar, V. A., Timofeeva, A. T., Pinelis, V. G., and Asanov, A. Y. (2018). MicroRNA expression profile in patients in the early stages of ischemic stroke. Neurol. Neuropsychiatry Psychosomat. 10, 72-78. doi: 10.1016/j.jpsychires.2019. 05.018

Zhao, H., Wang, J., Gao, L., Wang, R., Liu, X., Gao, Z., et al. (2013). MiRNA424 protects against permanent focal cerebral ischemia injury in mice involving suppressing microglia activation. Stroke 44, 1706-1713. doi: 10.1161/ STROKEAHA.111.000504

Zheng, L., Cheng, W., Wang, X., Yang, Z., Zhou, X., and Pan, C. (2017). Overexpression of MicroRNA-145 ameliorates astrocyte injury by targeting aquaporin 4 in cerebral ischemic stroke. BioMed. Res. Int. 2017:9530951. doi: $10.1155 / 2017 / 9530951$

Zheng, Z., Liu, S., Wang, C., and Han, X. (2018). A functional polymorphism rs145204276 in the promoter of long noncoding RNA GAS5 is associated with an increased risk of ischemic stroke. J. Stroke Cereb. Dis. 27, 3535-3541. doi: 10.1016/j.jstrokecerebrovasdis.2018.08.016

Zhu, M., Li, N., Luo, P., Jing, W., Wen, X., Liang, C., et al. (2018). Peripheral blood leukocyte expression of IncRNA MIAT and its diagnostic and prognostic value in ischemic stroke. J. Stroke Cereb. Dis. 27, 326-337. doi: 10.1016/j. jstrokecerebrovasdis.2017.09.009

Zhu, W., Tian, L., Yue, X., Liu, J., Fu, Y., and Yan, Y. (2019). LncRNA expression profiling of ischemic stroke during the transition from the acute to subacute stage. Front. Neurol. 10:36. doi: 10.3389/fneur.2019.00036

Zuo, M.-L., Wang, A.-P., Song, G.-L., and Yang, Z.-B. (2020). miR-652 protects rats from cerebral ischemia/reperfusion oxidative stress injury by directly targeting NOX2. Biomed. Pharmacotherapy. 124:109860. doi: 10.1016/j.biopha.2020. 109860

Conflict of Interest: The authors declare that the research was conducted in the absence of any commercial or financial relationships that could be construed as a potential conflict of interest.

The reviewer RE declared a shared affiliation with several of the authors, SG-F, ZS-F, and NA, to the handling editor at the time of the review.

Publisher's Note: All claims expressed in this article are solely those of the authors and do not necessarily represent those of their affiliated organizations, or those of the publisher, the editors and the reviewers. Any product that may be evaluated in this article, or claim that may be made by its manufacturer, is not guaranteed or endorsed by the publisher.

Copyright (C) 2021 Ghafouri-Fard, Shirvani-Farsani, Hussen, Taheri and Arefian. This is an open-access article distributed under the terms of the Creative Commons Attribution License (CC BY). The use, distribution or reproduction in other forums is permitted, provided the original author(s) and the copyright owner(s) are credited and that the original publication in this journal is cited, in accordance with accepted academic practice. No use, distribution or reproduction is permitted which does not comply with these terms. 